\title{
Latest Evidence-Based Application for Radiofrequency Neurotomy (LEARN): Best Practice Guidelines from the American Society of Pain and Neuroscience (ASPN)
}

\author{
David W Lee' \\ Scott Pritzlaff ${ }^{2,3}$ \\ Michael J Jung ${ }^{2,3}$ \\ Priyanka Ghosh ${ }^{4}$ \\ Jonathan $M$ Hagedorn (iD ${ }^{5}$ \\ Jordan Tate ${ }^{6}$ \\ Keith Scarfo ${ }^{7}$ \\ Natalie Strand iD ${ }^{8}$ \\ Krishnan Chakravarthy ${ }^{9,10}$ \\ Dawood Sayed (iD) 11 \\ Timothy R Deer (iD 12 \\ Kasra Amirdelfan ${ }^{13}$ \\ 'Fullerton Orthopedic Surgery Medical \\ Group, Fullerton, CA, 9283I, USA; \\ ${ }^{2}$ University of California, Davis; ${ }^{3}$ Division \\ of Pain Medicine, Sacramento, CA, USA; \\ ${ }^{4}$ ReMedy Medical Group, San Francisco, \\ CA, USA; ${ }^{5}$ Department of \\ Anesthesiology and Perioperative \\ Medicine, Division of Pain Medicine, \\ Mayo Clinic, Rochester, MN, USA; \\ ${ }^{6}$ Alliance Spine and Pain Centers, Canton, \\ GA, USA; ${ }^{7}$ Warren Alpert Medical \\ School of Brown University Department \\ of Neurosurgery - Norman Prince Spine \\ Institute, Rhode Island Hospital, \\ Providence, RI, USA; ${ }^{8}$ Department of \\ Anesthesiology and Perioperative \\ Medicine, Division of Pain Medicine, \\ Mayo Clinic, Phoenix, AZ, USA: \\ 'University of California, San Diego; \\ ${ }^{10}$ Division of Pain Medicine, San Diego, \\ CA, USA; "'University of Kansas Medical \\ Center, Kansas City, KS, USA; ${ }^{2}$ The \\ Spine and Nerve Center of the Virginias, \\ Inc., Charleston, WV, USA; ${ }^{13}$ IPM Medical \\ Group, Inc., Walnut Creek, CA, USA
}

Correspondence: David W Lee Fullerton Orthopedic Surgery Medical Group, 680 Langsdorf Dr Suite 103,

Fullerton, CA, 9283I, USA

Tel + I 7|4-879-0050

Email lee.davidw@gmail.com

\begin{abstract}
Radiofrequency neurotomy (RFN), also known as radiofrequency ablation (RFA), is a common interventional procedure used to treat pain from an innervated structure. RFN has historically been used to treat chronic facet-joint mediated pain. The use of RFN has more recently expanded beyond facet-joint mediated pain to peripherally innervated targets. In addition, there has also been the emergence of different radiofrequency modalities, including pulsed and cooled RFN. The use of RFN has been particularly important where conservative and/or surgical measures have failed to provide pain relief. With the emergence of this therapeutic option and its novel applications, the American Society of Pain and Neuroscience (ASPN) identified the need for formal evidence-based guidance. The authors formed a multidisciplinary work group tasked to examine the latest evidence-based medicine for the various applications of RFN, including cervical, thoracic, lumbar spine; posterior sacroiliac joint pain; hip and knee joints; and occipital neuralgia. Best practice guidelines, evidence and consensus grading were provided for each anatomical target.
\end{abstract}

Keywords: radiofrequency neurotomy, radiofrequency ablation, pulsed ablation, cooled ablation, sacroiliac joint neurotomy, peripheral joint neurotomy, occipital neuralgia, chronic pain

\section{Introduction}

Radiofrequency neurotomy (RFN), also known as radiofrequency ablation (RFA), is a standard procedure performed to treat pain from an innervated structure. Increased utilization of RFN has been driven by an aging population, a desire to avoid more invasive procedures, and the desire for an alternative to less efficacious and higher risk options, such as chronic long-term opioid therapy. Historically, RFN has been used to treat chronic facet-joint mediated pain diagnosed by facet or medial branch blocks. With the expanded use of this therapy for novel applications involving peripheral joints and nerves, there was an identified need for evidencebased best practice guidance. In addition, there has also been the emergence of different radiofrequency modalities, including pulsed and cooled RFN. This review aims to present the most up-to-date use of radiofrequency neurotomy based on anatomical targets. 


\section{History of Radiofrequency Neurotomy}

In the early 1930s, Kirschner demonstrated the first known utilization of RFN with thermocoagulation of the Gasserian ganglion for trigeminal neuralgia. Kirschner's initial work demonstrated that continuous radiofrequency (CRF) current created a focal thermal lesion in a neural pathway with the goal to interrupt nociception. ${ }^{1}$ Two decades later, in the 1950s, work by Aronow and Cosman would lead to the advent of the first commercially available radiofrequency (RF) systems. Shealy and Bogduk would later refine percutaneous medial branch RF neurotomy techniques, ${ }^{2}$ a procedure that essentially replaced surgical neurotomy. Initially, limitations in technology only allowed for the treatment of cervical and lumbar facet disease. However, CRF has now been studied in the treatment of numerous pain pathologies. Despite the technological advances, the risk of motor deficit remains a concern. ${ }^{3-6}$

Pulsed radiofrequency (PRF) technology, first introduced in Austria in 1995, was developed to reduce the risk of motor deficit as it does not create a destructive thermal lesion. Ayrapetyan proposed that PRF efficacy may be secondary to magnetic field exposure as opposed to thermal coagulation. ${ }^{7}$ In 1998, the first article on the effects of PRF on the dorsal root ganglion was published. ${ }^{8-10}$

A recent novel modality for ablation of neural pathways is cooled radiofrequency (CRFN) thermal neurotomy. Despite the name, this technique allows for a larger thermal lesion to be formed than traditional RFN (Figure 1). This method has been increasingly utilized for the interruption of nociceptive pathways after its initial use in cardiac electrophysiology and tumor ablation. Since 2010 , there has been emerging evidence supporting the use of CRFN for chronic knee, hip and back pain. ${ }^{11-13}$

\section{Methods}

Based on the identified gap in guidance on the use of RFN, the American Society of Pain and Neuroscience (ASPN) formed a multidisciplinary work group of pain medicine specialists to create a best practice guideline. Selection of panel members was based on expertise, publications, research, clinical experience, practice setting and diversity. All work group members actively utilize RFN in their respective practices. While there have been previous publications on the use of RFN, work group members

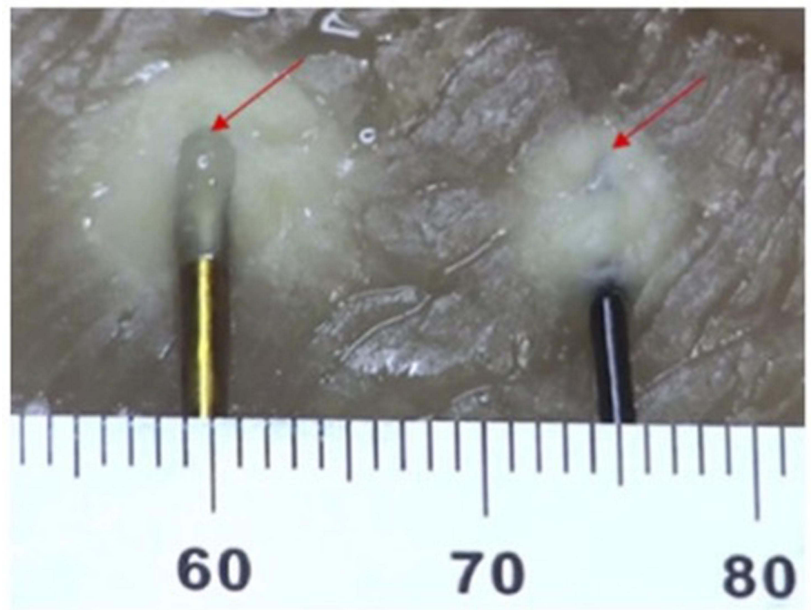

Figure I Lesioning performed in chicken breast $\left(37^{\circ} \mathrm{C}\right)$. Left probe, Cooled RF I8G with $4 \mathrm{~mm}$ active tip, set temperature of $60^{\circ} \mathrm{C}$. Right probe, Standard RF with $20 \mathrm{G}$ with $5 \mathrm{~mm}$ active tip, set temperature $80^{\circ} \mathrm{C}$. Arrow annotates the location of the probe tips. Used with permission from Avanos Medical, Inc.

identified the need to expand best practice guidelines to address sacroiliac joint pain and peripheral joint disease. The aim of the paper was to present the most up-to-date use of this modality based on anatomical targets.

A formal literature search was performed by the authors with clinical experience in RFN procedures. Database searches of Embase, PubMed and Medline, utilizing the following keywords was performed: cervical radiofrequency neurotomy/ablation, thoracic radiofrequency neurotomy/ablation, lumbar radiofrequency neurotomy/ablation, sacroiliac joint radiofrequency neurotomy/ablation, lateral sacral branch neurotomy/ablation, hip radiofrequency neurotomy/ablation, genicular radiofrequency neurotomy/ablation, knee radiofrequency neurotomy/ablation, and occipital radiofrequency neurotomy/ablation. The terms neurotomy and ablation are used interchangeably in this paper. In addition, the terms facet, medial branch, and medial branch nerves are used interchangeably in this paper.

Inclusion criteria for literature search were randomized controlled trials, prospective and retrospective observational studies. Exclusion criteria included conference proceedings, expert opinions, and unpublished data. The records were filtered for "pain management" specific topics. The remaining abstracts were reviewed by two authors utilizing PICOS technique with comparison to other treatment (active, sham or placebo) or no treatment, and outcome measures to include improvement in pain by any scale. Secondary outcomes of interest: function, analgesic use, subsequent need for surgery, healthcare 
utilization, return to work. The screened manuscripts were then separated by anatomic targets:

1. Cervical Medial Branches

2. Thoracic Medial Branches

3. Lumbar Medial Branches

4. Lateral Sacral Branches (Posterior sacroiliac ligaments and joint)

5. Knee Joints

6. Hip Joints

7. Occipital Nerve Branches

A formal meta-analysis was not conducted due to heterogeneity in study types, diagnostic criteria, variances in interventional techniques utilized and discrepancies in primary and secondary endpoints. Literature review was conducted by each work group member for assessment of both quality of evidence and grade of recommendation. Any discrepancies in grading were brought to the work group for discussion so that a consensus could be reached. In the end, there were no discrepancies to disclose. Each section includes a summary of:

1. The most current evidence-based medicine for the use of RFN

2. Patient selection guidance

3. Procedure techniques and best practice recommendations

4. Treatment and research gaps.

5. Quality of evidence for each anatomic target graded from I-III as detailed in Table 1.

Table I Quality of Evidence, Based on the USPSTF Criteria

\begin{tabular}{|l|l|}
\hline $\begin{array}{l}\text { Evidence } \\
\text { Level }\end{array}$ & Definition \\
\hline I & $\begin{array}{l}\text { At least one controlled and randomized clinical trial } \\
\text { with proper design }\end{array}$ \\
\hline II-I & $\begin{array}{l}\text { Well designed, controlled, nonrandomized clinical } \\
\text { trial }\end{array}$ \\
\hline II-2 & $\begin{array}{l}\text { Cohort or case studies add well designed controls, } \\
\text { preferably multicenter }\end{array}$ \\
\hline II-3 & $\begin{array}{l}\text { Multiple series compared over time, with or without } \\
\text { intervention, and surprising results }\end{array}$ \\
\hline III & Experience driven opinions, clinical observations \\
\hline
\end{tabular}

6. Consensus statement and expert opinion analysis were rendered using the US Preventive Services Task Force (USPSTF) grading scale (Table 2). The Task Force assigns to each of its recommendations a letter grade (A, B, C, or D) or issues an "I" statement, based on the certainty of the evidence and on the balance of benefits and harms of the preventive service. The USPSTF updated its definitions of the grades it assigns to recommendations and now includes "suggestions for practice" associated with each grade.

Conflict of Interest Management: Each member of the panel recused itself from any decision in which a conflict existed. One author (KA) had the responsibility of evaluating the paper for bias and resolving any potential issues prior to manuscript publication.

\section{Cervical Medial Branch Radiofrequency Neurotomy}

Cervical medial branch RFN, also commonly referred to as cervical facet joint neurotomy or ablation, is used for the treatment of chronic neck pain and cervicogenic headache. ${ }^{14}$ While physical examination and imaging may support the diagnosis of cervical facet-mediated pain, these alone have not been validated as standalone diagnostic techniques. Neck tenderness or pain with extension and/or rotational movements, though often associated with cervical facet joint mediated pain, are not specific to solely facet-mediated pain. ${ }^{15}$ While commonly used diagnostically in pain medicine, diagnostic cervical medial branch/facet blocks are not specifically covered in this manuscript as they are beyond the scope of this paper. ${ }^{16}$

\section{Current Available Evidence of Cervical Medial Branch Radiofrequency Neurotomy}

Early descriptive studies of radiofrequency neurotomy date back half a century; recent studies are summarized in Table 3.

\section{Procedure Techniques}

The effectiveness of the cervical RFN is highly dependent on proper technique. ${ }^{24}$ There is robust evidence for shortand long-term pain relief with denervation protocols involving multiple lesions. ${ }^{25}$ This technique has since been adopted as the standard of care. ${ }^{24}$ 
Table 2 Recommendation Grade Level

\begin{tabular}{|c|c|c|}
\hline Grade & Definition & Suggestions for Practice \\
\hline A & $\begin{array}{l}\text { The USPSTF recommends the service. There is high certainty that } \\
\text { the net benefit is substantial. }\end{array}$ & Offer or provide this service. \\
\hline B & $\begin{array}{l}\text { The USPSTF recommends the service. There is high certainty that } \\
\text { the net benefit is moderate or there is moderate certainty that the } \\
\text { net benefit is moderate to substantial. }\end{array}$ & Offer or provide this service. \\
\hline C & $\begin{array}{l}\text { The USPSTF recommends selectively offering or providing this } \\
\text { service to individual patients based on professional judgment and } \\
\text { patient preferences. There is at least moderate certainty that the } \\
\text { net benefit is small. }\end{array}$ & $\begin{array}{l}\text { Offer or provide this service for selected patients depending on } \\
\text { individual circumstances. }\end{array}$ \\
\hline D & $\begin{array}{l}\text { The USPSTF recommends against the service. There is moderate } \\
\text { or high certainty that the service has no net benefit or that the } \\
\text { harms outweigh the benefits. }\end{array}$ & Discourage the use of this service. \\
\hline I & $\begin{array}{l}\text { The USPSTF concludes that the current evidence is insufficient to } \\
\text { assess the balance of benefits and harms of the service. Evidence is } \\
\text { lacking, of poor quality, or conflicting, and the balance of benefits } \\
\text { and harms cannot be determined. }\end{array}$ & $\begin{array}{l}\text { Read the clinical considerations section of USPSTF } \\
\text { Recommendation Statement. If the service is offered, patients } \\
\text { should understand the uncertainty about the balance of benefits } \\
\text { and harms. }\end{array}$ \\
\hline
\end{tabular}

Table 3 Studies of Cervical Medial Branch Radiofrequency Neurotomy

\begin{tabular}{|c|c|c|}
\hline Author, Year & Study Type & Results \\
\hline Lord et al $1995^{17}$ & Clinical study & $\begin{array}{l}19 \text { subjects and } 21 \text { joints treated, there were } \mathrm{C} 2-3 \text { zygapophysial joints }(\mathrm{N}=10) \text { and additional } \mathrm{C} 5, \mathrm{C} 6, \mathrm{C} 7 \\
\text { medial branches. Only } 4 \text { of } 10 \text { patients obtained relief following neurotomy for } \mathrm{C} 2-\mathrm{C} 3 \text { zygapophysial joint } \\
\text { pain. Severe out of } 10 \text { patients who underwent lower cervical medial branch neurotomy obtained complete } \\
\text { pain relief and were able to resume their activities of daily living and employment. }\end{array}$ \\
\hline Lord et al $1996^{18}$ & RCT & $\begin{array}{l}24 \text { patients with chronic neck pain underwent cervical radiofrequency. At } 6 \text { months, } 7 / 12(58 \%) \text { patients in } \\
\text { the active treatment group and I/I2 (8\%) in the control group were pain-free. Median time of return of pain } \\
\text { was } 263 \text { days in the treatment group compared to } 8 \text { days in the control group. }\end{array}$ \\
\hline Shin et al $2006^{19}$ & Clinical study & $\begin{array}{l}28 \text { consecutive patients underwent RFN. } 69 \% \text { of patients treated reported successful outcomes after } 6 \\
\text { months, with } 29 \% \text { reporting complete pain relief. }\end{array}$ \\
\hline $\begin{array}{l}\text { Sapir and Gorup } \\
2001^{20}\end{array}$ & Clinical study & $\begin{array}{l}\text { RFN was performed on } 46 \text { patients ( } 29 \text { litigants and } 17 \text { non-litigants). } 25 \text { patients were asymptomatic at one- } \\
\text { year follow-up. The average time of return of pain of } 50 \% \text {, for those } 21 \text { patients who had pain before } 12 \\
\text { months, was } 8.3 \pm 2.3 \text { months. }\end{array}$ \\
\hline $\begin{array}{l}\text { McDonald et al } \\
1999^{21}\end{array}$ & Clinical study & $\begin{array}{l}28 \text { patients with cervical facet joint pain diagnosed by comparative anesthetic blocks. RFN was performed, } \\
\text { and repeated upon return of pain, with primary outcome measures of pain relief and duration of benefit. } 18 \\
\text { of the } 28 \text { patients had greater than } 3 \text { months of complete pain relief. Median duration of pain relief was } 421.5 \\
\text { days. The median duration of pain relief for all participants was } 218.5 \text { days. The study confirmed that lengthy, } \\
\text { but not permanent relief from RFN is possible with repeat utilization. }\end{array}$ \\
\hline $\begin{array}{l}\text { MacVicar et al } \\
2012^{22}\end{array}$ & Clinical study & $\begin{array}{l}\text { Cervical RFN was successful in } 74 \% \text { and } 61 \% \text { of patients in two separate sites. Clinical success was defined as } \\
\text { at least } 80 \% \text { pain relief for } 6 \text { months. Average duration of relief from initial RFN was } 17-20 \text { months, and I5 } \\
\text { months following repeat RFN treatments. }\end{array}$ \\
\hline Barnsley $2005^{23}$ & $\begin{array}{l}\text { Observational } \\
\text { study }\end{array}$ & $\begin{array}{l}35 \text { consecutive patients met all diagnostic criteria for cervical facet joint pain. For the RFN procedure, the } \\
\text { electrode was introduced twice; along a parasagittal path to reach the medial branch as it crosses the lateral } \\
\text { articular pillar, and at a } 30 \text { degree angle to the sagittal plane to reach the medial branch over the anterolateral } \\
\text { aspect of the cervical pillar. Two or three lesions were made at each location to accommodate for possible } \\
\text { variation in the course of the nerve ( } 80 \text { degrees Centigrade for } 90 \text { seconds). } 26 \text { (74\%) patients treated } \\
\text { obtained complete relief of pain for a mean duration of } 35 \text { weeks ( } 8.7 \text { months). Among the responders, } 21 \\
\text { obtained complete relief in excess of } 12 \text { weeks. }\end{array}$ \\
\hline
\end{tabular}


In its most rigorous adoption, cervical medial branch RFN is a two-step procedure: (1) oblique insertion and (2) sagittal insertion, which allows for lesions at two separate sites along the trajectory increasing the area of the thermal lesion. The oblique pass is intended to place lesions over the anterior third of the superior articular process. The sagittal pass is intended to place lesions along the lateral aspect of the articular pillar in which the medial branch nerve is located (Figure 2).

\section{Best Practices Summary}

- Use of cervical RFN is primarily for symptoms of axial neck pain in the absence of radicular symptoms.

- Prior to RF of the cervical spine, other possible etiologies should be ruled out. The use of magnetic resonance imaging (MRI) and/or computerized tomography (CT) imaging is highly recommended, but $\mathrm{x}$-rays can also very useful. Although imaging can characterize degenerative changes, it is not a diagnostic for facet-mediated pain. Additionally, discogenic changes do not necessarily rule out the use of RFN.

- Physical examination and radiographic findings have no direct diagnostic or prognostic value in determining success of radiofrequency procedures.

- The efficacy of RFN is directly related to the rigor of diagnostic blocks performed as well as the use of proper technique for both diagnostic and neurotomy procedures.

- Evidence best supports the use of conventional thermal (60-80 degree centigrade) radiofrequency for
60-90 seconds. While the use of pulsed RF on the cervical medial branches has been reported, further studies are necessary.

- Multiple passes, and utilizing two separate approaches, may allow for neurotomy in a larger portion of the medial branch, resulting in improved pain relief with longer duration.

- If neck pain recurs, evidence supports the use of repeat neurotomy with reproducible efficacy. Although timing is highly variable, the procedure may be repeated as early as every six months. ${ }^{26}$

\section{Treatment Gaps \& Future Research}

Research and evidence gaps exist for cervical medial branch pulsed radiofrequency (PRF). PRF allows for the application of radiofrequency current at lower temperatures, minimizing the damage to surrounding tissue, nerves and/or vasculature. Further research on PRF is required to determine both the efficacy and the safety of this treatment modality, and how it compares to conventional RF. Although several studies have demonstrated the efficacy of both continuous and pulsed RF within the range of 6 to 12 months, more evidence is clearly needed.

\section{Consensus Statement}

Cervical medial branch radiofrequency neurotomy may be used for the treatment of axial neck pain when facet joints have been identified as the etiology of pain via diagnostic blocks. GRADE I A.
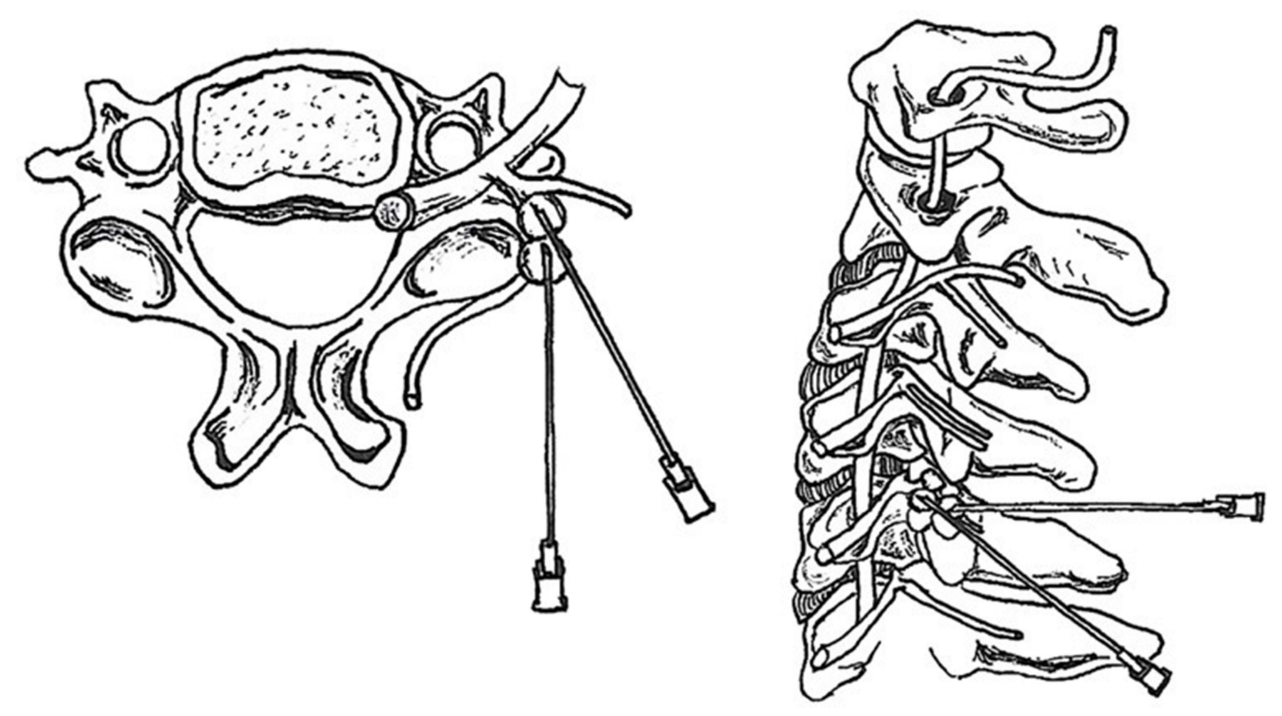

Figure 2 Axial and lateral illustrations of optimal radiofrequency needle placement for both parasagittal and oblique passes. 


\section{Thoracic Medial Branch Radiofrequency Neurotomy}

Thoracic medial branch RFN is used for the treatment of chronic thoracic/midback pain. ${ }^{27}$ Since physical exam and radiographic techniques are variable and difficult to interpret in these instances, diagnosis of thoracic facet joint pain relies mainly on diagnostic injections. In those cases of positive diagnostic medial branch blocks, the patient may find long-term relief with thoracic RFN.

\section{Current Available Evidence of Thoracic Medial Branch Radiofrequency Neurotomy}

The literature surrounding the use of thoracic medial branch RFN is relatively scarce when compared to other levels of the spine. Interestingly, multiple modalities of RFN have been studied in the thoracic spine, albeit with low level of evidence. The published literature is summarized in Table 4.

\section{Procedure Techniques}

As with all ablation techniques, the effectiveness of the therapy is highly dependent on proper technique and appropriate lesioning of the thoracic medial branch nerves. Using either an anteroposterior (AP) or ipsilateral oblique fluoroscopic image, the radiofrequency cannula is directed in a caudal-to-cephalad direction and advanced towards the superolateral edge of the targeted thoracic transverse process. This is the site of the thoracic medial branch as it courses along the transverse process (Figure 3). The ablation is performed per standard protocol based on ablation modality.

\section{Best Practices Summary}

- The use of thoracic RFN is indicated for axial midback pain in the absence of radicular symptoms.

Table 4 Studies of Thoracic Medial Branch Radiofrequency Neurotomy

\begin{tabular}{|c|c|c|}
\hline Author, Year & Study Type & Results \\
\hline Joo et al $2013^{28}$ & RCT & $\begin{array}{l}\text { In the only thoracic RFA RCT to date, Joo et al studied the effects of alcohol ablation versus thermal RFA } \\
\text { to the thoracic medial branches in patients with recurrent thoracic facet joint pain after prior thermal RFA } \\
\text { treatment. Forty patients with recurrent thoracic facet joint pain following prior successful thermal RFA } \\
\text { were randomly assigned to one of two groups: repeat thermal RFA or alcohol ablation. The recurrence } \\
\text { rate of thoracic facet joint pain was assessed with NRS and ODI during the following } 24 \text { months. The } \\
\text { results showed that alcohol ablation was significantly more likely to avoid pain recurrence than thermal RFA } \\
\text { (defined as NRS }<7 \text { and ODI }<22 \% \text {; }<0.000 \text { ). The median effective time in the thermal RFA group was I0.7 } \\
\text { months (range } 5.4-24 \text { months) and in the alcohol ablation group was } 24 \text { months (range } 16.8-24 \text { months). } \\
\text { No significant complications were observed in either group. }\end{array}$ \\
\hline Chang $2018^{29}$ & $\begin{array}{l}\text { Prospective } \\
\text { case series }\end{array}$ & $\begin{array}{l}\text { Chang reported on the effects of pulsed RFA to the thoracic medial branches in } 20 \text { patients with chronic } \\
\text { thoracic facet joint pain. Before enrollment, all patients experienced } \geq 80 \% \text { temporary pain relief with } \\
\text { a diagnostic thoracic MBB with } 0.5 \mathrm{~mL} \text { of } \mathrm{I} \% \text { lidocaine. After successful diagnostic blocks, patients } \\
\text { underwent pulsed RFA with settings at } 5 \mathrm{~Hz} \text { and a } 5 \text {-millisecond pulse width for } 360 \text { seconds at } 45 \mathrm{~V} \text {. The } \\
\text { NRS was recorded at baseline, and at I-, } 2 \text {-, and } 3 \text {-months following treatment. Mean NRS was } 6.0 \text { at } \\
\text { baseline and } 4.0 \text { at three months post-procedure }(p<0.05 \text { ). Eleven of } 20 \text { patients }(55 \%) \text { reported pain relief } \\
\geq 50 \% \text { at three months post-procedure. }\end{array}$ \\
\hline $\begin{array}{l}\text { Rohof and Chen } \\
2018^{30}\end{array}$ & $\begin{array}{l}\text { Retrospective } \\
\text { study }\end{array}$ & $\begin{array}{l}\text { A retrospective study of } 7 \text { I patients whom following a successful diagnostic medial branch block underwent } \\
\text { bipolar RFA. Eighty-two percent of patients had } \geq 50 \% \text { pain relief at } 12 \text { months post-procedure. Baseline } \\
\text { mean NRS was } 7.75 \pm I .25 \text { which was decreased to } 2.82 \pm I .29 \text { at } 12 \text { months post-procedure (mean } 63.6 \% \text {; } \\
\mathrm{p}<0.00 \text { I). There were no complications reported. }\end{array}$ \\
\hline $\begin{array}{l}\text { Gungor and } \\
\text { Candan } 2020^{31}\end{array}$ & $\begin{array}{l}\text { Retrospective } \\
\text { study }\end{array}$ & $\begin{array}{l}\text { Cooled RFA (CRFA) is a newer RFA technique that can create a larger spherical lesion. Subsequently, there } \\
\text { is an increased likelihood of including the medial branches in the thoracic spine within the created lesion. } \\
\text { Gungor and Candan performed a retrospective study investigating the efficacy of CRFA in the treatment of } \\
\text { thoracic facet-related pain. In this study, } 40 \text { CRFA procedures were performed on } 23 \text { individual patients } \\
\text { following successful diagnostic medial branch blocks ( } \geq 80 \% \text { temporary pain relief). The investigators } \\
\text { assessed NRS scores pre- and post-treatment. At } 6-12 \text { month follow-up, mean pain relief was } 37.6 \% \text {. }\end{array}$ \\
\hline
\end{tabular}



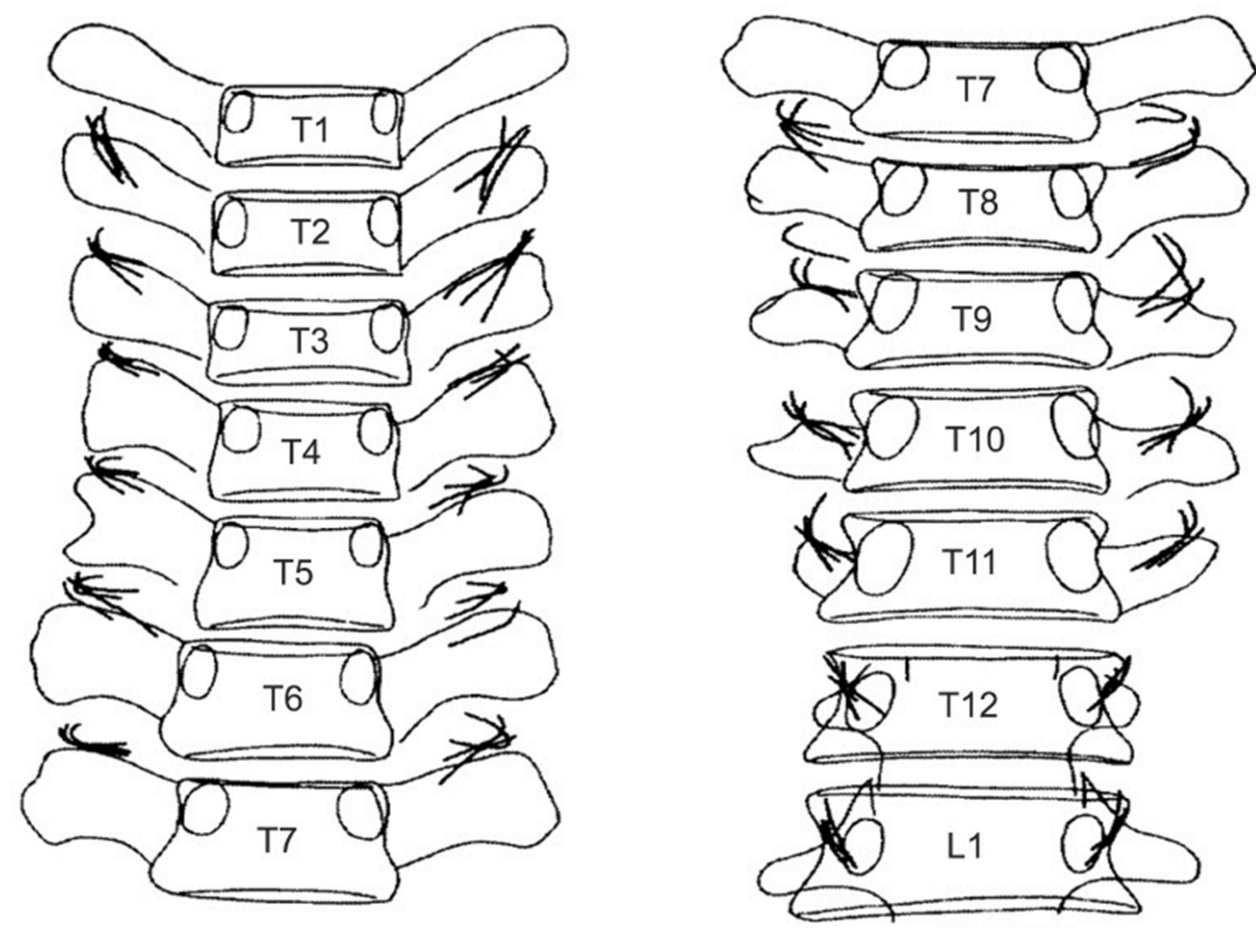

Figure 3 Variation in the position of the thoracic medial branches. Reproduced with permission from Bogduk N (ed). Practice Guidelines for Spinal Diagnostic and Treatment Procedures, 2nd edn. International Spine Intervention Society, San Francisco, 2013.39

- Low-level evidence suggests that traditional RFA and bipolar RFA may provide longer lasting pain relief than pulsed RFA and CRFA, but given the study's methodological differences, it is impossible to draw any firm conclusions.

- Given the location and anatomic variability of thoracic medial branches, patients should be counseled about the risk of pneumothorax. Physicians should have a sound understanding of thoracic fluoroscopic anatomy prior to performing thoracic RFN.

- If thoracic pain recurs, evidence suggests that repeat RFN is effective. In the only RCT involving thoracic spine RFN, alcohol ablation was shown to be more efficacious than traditional RFA.

\section{Treatment Gaps \& Future Research}

Overall, there is a paucity of quality research and publications addressing thoracic medial branch RFN. Thoracic facetrelated back pain would benefit from high-quality research addressing basic questions, including comparison of different RFN modalities to conventional medical management and to each other in a prospective, long-term manner.

\section{Consensus Statement}

Thoracic medial branch radiofrequency neurotomy may be used for the treatment of thoracic/midback pain when facet joints have been identified as the etiology of pain via diagnostic blocks. GRADE II-3 C.

\section{Lumbar Medial Branch Radiofrequency Neurotomy}

Lumbar radiofrequency neurotomy (LRFN) is the second most common procedure performed in interventional pain practices in the United States. ${ }^{32}$ This procedure is also commonly referred to as lumbar medial branch nerve RFN. There has been a $130.6 \%$ increase in its utilization from 2007 to $2016 .^{33,34}$ Low back pain (LBP) due to lumbar facet joint disease is often treated with LRFN. This diagnosis is prevalent in approximately $45 \%$ of lower back pain patients. ${ }^{35-38}$ While LRFN is one of the best studied interventional pain procedures, it is also one of the most debated procedures with constantly evolving evidence. ${ }^{39,40}$ 


\section{Current Available Evidence of Lumbar Medial Branch Radiofrequency Neurotomy}

Diagnosing lumbar facet pain is challenging due to its heterogeneous etiology, variable clinical findings, radiographic and clinical course, and the multifactorial nature of low back pain. ${ }^{39,40}$ Patients generally complain of axial low back pain with or without radiation into the groin, buttocks, and/or thighs. Axial pain may worsen with extension, lateral bending, rotation, sitting, standing, walking or coughing. ${ }^{41}$ Consistent with other arthritic pain, this pain is often worsened by immobility. However, the published evidence does not find these symptoms to correlate well with the success of LRFN. ${ }^{42}$ Physical examination findings also have similarly mixed outcomes in the literature. The most studied and utilized physical examination techniques, including "facet loading" or paravertebral tenderness, have minimal ability to reliably predict the efficacy of LRFN. ${ }^{43}$ Hence, the literature illustrates that there are no pathognomonic signs with both clinical history and physical examination to reliably diagnose patients with facet-mediated pain or predict the success of LRFN. ${ }^{43-45}$ Moreover, both MRI and CT scans have no specific findings that help diagnose lumbar facet mediated pathology as the exclusive source of pain. ${ }^{46,47}$

As such, the present standard in the diagnosis of lumbar facet mediated pain is diagnostic facet blocks, including both the use of intra-articular facet joint injections and medial branch nerve blocks. ${ }^{43}$ Medial branch blocks are considered more predictive for lumbar medial branch RFN success than intra-articular facet injections; however, both techniques have shown better predictive value compared to sham. ${ }^{47}$ The optimal volume of anesthetic injectate for diagnostic medial branch blocks recommended is $<0.5 \mathrm{cc}$ in order to improve specificity and reduce the risk of spreading to adjacent nerves or structures.

LRFN has been studied extensively with consensus guidelines indicating moderate to strong evidence. ${ }^{43-45}$ The efficacy of the lumbar medial branch RFN has been described in observational and RCT. Out of the six RCTs, three contained technical flaws in both patient selection and procedural technique, which yielded less reliable and therefore, non-generalizable findings. ${ }^{54-56}$ Of the literature that is published with acceptable methodology and generalizability, patient benefit from lumbar medial branch RFN is well documented. Table 5 summarizes LRFN studies.

\section{Procedure Techniques}

Successful treatment of lumbar facet pain by RFN is contingent on nerve coagulation by heat. ${ }^{60}$ The lumbar facet joints are paired, with each joint innervated by the medial branches from the dorsal rami of the same level, as well as the level above. Bogduk et al demonstrated the target for lumbar neurotomy to be the medial branches of the lumbar dorsal rami in their landmark study. ${ }^{61}$ In order to target these nerves appropriately, RF needles are placed along the posterior elements of the lumbar vertebral column, at the junction of the superior articular and the transverse processes of the vertebrae. ${ }^{61}$ At the L5 level, the dorsal ramus itself is amenable to neurotomy, which runs at the junction of the $\mathrm{S} 1$ superior articular process and the sacral ala.

The optimal electrode positioning has now been demonstrated to be parallel to the target nerves after the initial thought process that a perpendicular needle placement may be sufficient ${ }^{61-63}$ (Figure 4). While the studies varied in their design, the consensus was that the parallel placement of traditional electrodes is indeed the optimal approach for LRFN. $^{33,42,47}$

Motor and sensory testing is often suggested prior to RFN, in order to confirm appropriate and safe placement of the electrode tip. As such, injury to the ventral ramus or any other unintended structures may be avoided. This is a topic that has been widely studied and debated. ${ }^{64}$ There have been case studies with nerve root injury where motor stimulation was not performed. ${ }^{65}$ Given the limited data, even society guidelines are mixed on utilizing sensory and motor stimulation prior to lumbar medial branch RFN. ${ }^{47}$ Finally, a recent expert consensus statement recommended sensory stimulation with single-level lesions, with low level of certainty and inconclusive evidence with multiple lesions. Motor stimulation is recommended for both safety and effectiveness purposes. ${ }^{33}$

\section{Best Practices Summary}

- Use of lumbar radiofrequency neurotomy (LRFN) is primarily for symptoms of low back pain in the absence of radicular symptoms.

- Prior to LRFN, other possible etiologies by way of either MRI or CT imaging should be ruled out, although imaging is not itself a diagnostic for facetmediated pain. Discogenic changes do not necessarily rule-out the use of LRFN.

- Medial branch blocks are generally considered more predictive for success with LRFN than intra-articular facet injections. 
Table 5 Summary of LRFN Studies

\begin{tabular}{|c|c|c|}
\hline Author, Year & Study Type & Results \\
\hline Lee et al $2017^{48}$ & Meta-analysis & $\begin{array}{l}\text { Included } 7 \text { randomized controlled trials (RCT). Concluded RFN groups had significant } \\
\text { improvement in pain scores at one-year post-procedure compared to sham and sacroiliac joint } \\
\text { pain compared to conservative, non-interventional approaches, revealed a significantly greater } \\
\text { improvement in ODI, pain scores and quality of life in the RFN arm compared to the control } \\
\text { arm. }\end{array}$ \\
\hline Shih et al $2020^{49}$ & Meta-analysis & $\begin{array}{l}\text { Radiofrequency offer significant improvement in lumbar facet joint or sacroiliac joint pain for up } \\
\text { to } 12 \text { months compared with baseline level of pain. }\end{array}$ \\
\hline Maas et al $2015^{50}$ & $\begin{array}{l}\text { Cochrane } \\
\text { review }\end{array}$ & $\begin{array}{l}\text { Review of RFN for chronic low back pain evaluated } 23 \text { studies; } 12 \text { studies examined suspected } \\
\text { facet joint pain. The authors found no high-quality evidence to suggest that RF denervation } \\
\text { provides pain relief or functional improvement for patients with CLBP. }\end{array}$ \\
\hline Poetscher et al $2014^{51}$ & $\begin{array}{l}\text { Literature } \\
\text { review }\end{array}$ & $\begin{array}{l}\text { This review examined nine studies and concluded there was low-to-moderate evidence favoring } \\
\text { lumbar medial branch RFN for pain control. }\end{array}$ \\
\hline Boswell et al $2015^{52}$ & $\begin{array}{l}\text { Systematic } \\
\text { review }\end{array}$ & $\begin{array}{l}\text { The available evidence is Level I for lumbar facet joint nerve blocks with the inclusion of } 17 \\
\text { studies with dual diagnostic blocks, with at least } 75 \% \text { pain relief with an average prevalence of } \\
16-41 \% \text { and false-positive rates of } 25 \%-44 \% \text {. }\end{array}$ \\
\hline Falco et al $2012^{53}$ & $\begin{array}{l}\text { Systematic } \\
\text { review }\end{array}$ & $\begin{array}{l}\text { II randomized trials and } 14 \text { observational studies met inclusion criteria for methodological } \\
\text { quality assessment. The review concluded that evidence for radiofrequency neurotomy is good } \\
\text { and fair-to-good for short- and long-term improvement; whereas the evidence for intraarticular } \\
\text { injections and pulsed radiofrequency neurotomy is limited. }\end{array}$ \\
\hline $\begin{array}{l}\text { Juch et al } 2017 \text {, and van } \\
\text { Kuijk et al } 2018^{54,57}\end{array}$ & $\begin{array}{l}\text { Randomized } \\
\text { control trial }\end{array}$ & $\begin{array}{l}\text { This study found no efficacy for lumbar medial branch RFN. However, this study has been } \\
\text { widely criticized as rife with flaws including significant issues with the technical aspects such as } \\
\text { electrode placement and orientation, statistical analysis, and non-stringent selection criteria } \\
\text { which leads the study to lack any generalizability. }\end{array}$ \\
\hline $\begin{array}{l}\text { Conger et al } 2019 \text { and Tekin } \\
\text { et al } 2007^{58,59}\end{array}$ & $\begin{array}{l}\text { Literature } \\
\text { review }\end{array}$ & $\begin{array}{l}\text { In addition to success of the initial lumbar medial branch RFN, the efficacy of repeat RFN, has } \\
\text { very high success rates in the literature, with } 3 \text { retrospective studies and I prospective study } \\
\text { showing a success rate }>85 \% \text { for repeated RFN treatment with duration of pain relief between } \\
10-12 \text { months. }\end{array}$ \\
\hline
\end{tabular}

- In addition to the success of the initial LRFN, the efficacy of repeat LRFN with pain recurrence has been shown to be highly reproducible.

- Optimal electrode positioning is parallel to the target nerves, although more evidence is necessary.

- Motor and sensory testing is recommended prior to LRFN, in order to confirm appropriate placement of the electrode tip and to avoid lesioning of any other unintended structures including the ventral ramus.

- Evidence best supports the use of conventional thermal (60-80 degree centigrade) radiofrequency for $60-90$ seconds. While the use of pulsed RF on the lumbar medial branches has been reported, further studies are necessary.

\section{Treatment Gaps \& Future Research}

Similar to the cervical region, pulsed radiofrequency (PRF) for the lumbar spine is not covered extensively in the literature. Further research in various forms of RF is needed to determine the efficacy and safety of these treatment modalities. Furthermore, additional research is clearly needed to confirm if a parallel needle placement is indeed the most optimal option, particularly in light of other modalities, such as cooled RF.

\section{Consensus Statement}

Lumbar medial branch radiofrequency neurotomy may be used for the treatment of axial low back pain when facet 


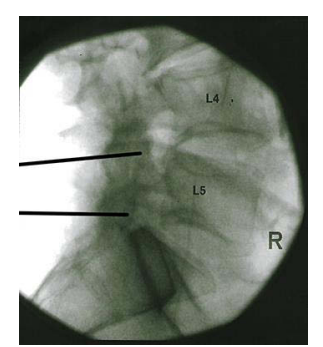

Figure 4 Illustration showing optimal radiofrequency needle placement parallel to the lumbar medial branch nerve.

joints have been identified as the etiology of pain via diagnostic blocks, GRADE I A.

\section{Lateral Sacral Branch Radiofrequency Neurotomy}

Early studies brought attention to the sacroiliac joint as a pain generator through reproduction of symptoms by way of provocative maneuvers and diagnostic/therapeutic injections into the sacroiliac joint (SIJ). ${ }^{66}$ Laslett et al found provocative maneuvers to be helpful but lacked sensitivity. ${ }^{66}$ There is no evidence to support any provocative SIJ maneuver as pathognomonic for SIJ pain; hence, the use of diagnostic SIJ blocks utilizing local anesthetics with or without steroids has evolved as the current standard. ${ }^{67}$ Although, initially, such injections were done blindly, image-guidance has substantially improved the accuracy of this procedure. However, therapeutic intra-articular injections only provide temporary relief for most patients. Recalcitrant cases led to the advent of other treatment options for SIJ dysfunction. RFN emerged as the most viable choice given its known evidence and effectiveness in treating facet-mediated pain. ${ }^{68}$

Histological analysis of the sacroiliac joint has verified the presence of nerve fibers within the joint capsule and adjoining ligaments. ${ }^{69}$ The sacroiliac joint is thought to receive its innervation from the ventral rami of L4 and L5, the dorsal rami of L5, S1, S2, and S3, as well as the superior gluteal nerve. ${ }^{70,71}$ There is an additional ventral innervation of the sacroiliac joint that is inaccessible for denervation.

Sacral lateral branch neurotomy addresses the posterior sacroiliac structures, which includes both the posterior joint and ligaments. Therefore, the response to intraarticular sacroiliac joint injections, per se, does not necessarily correlate to radiofrequency success. ${ }^{72}$ However, blocking the innervation lateral to the foramen at different depths has been shown to be more effective. However, there are no placebo-controlled trials for lateral sacral nerve blocks to confirm this thought process. ${ }^{72}$ This is a treatment gap in appropriately selecting patients for sacral lateral branch neurotomy.

\section{Current Available Evidence of Lateral Sacral Branch Radiofrequency Neurotomy}

Two controlled and two pragmatic RFN studies of the lateral sacral branch are described in Table 6 with the remaining lateral sacral branch radiofrequency neurotomy studies being observational.

\section{Procedure Techniques}

The variability in the position of the posterior lateral sacral branches makes diagnostic blocks a technical challenge. As such, monopolar lesions may not necessarily reliably capture the nerve, which has led to the advent of cooled or bipolar RF lesion strategies. There are various studies comparing different forms of RFN of the SIJ; however, results are inconsistent and the study designs have variable patient selection lending to discrepancies in neurotomy techniques used. ${ }^{73,80}$ For this reason, monopolar lesions continue to be used as a treatment option; however, multiple lesions along the suspected trajectory of the lateral branches are recommended.

Roberts et al conducted one of the most comprehensive cadaveric anatomical studies to date on the anatomic location of the lateral sacral branches. ${ }^{90}$ The lateral branches were dissected out, and radiopaque wires were directly sutured to them. Anterior-posterior fluoroscopic imaging through the S1 superior endplate was obtained. Lesions by 17 versions of seven current sacroiliac joint RF techniques were mapped on fluoroscopic images. The techniques are meticulously described within this manuscript and were compared for:

1) Percentage of lateral branches captured

2) Percentage of SIJ specimens in which $100 \%$ of lateral branches were captured

3) Percentage of lateral branches that would not be captured at each level.

The results demonstrated that bipolar techniques captured a greater percentage of the lateral branches than traditionally used monopolar techniques. Furthermore, monopolar capture rates ranged from $49.6 \%$ to $64.6 \%$, likely due to the small lesion size created by this technique.

Regarding the locations of the actual thermal lesion, it was found that the use of the palisade technique (Figure 5) was the most optimal in capturing the lateral branches. The 
Table 6 Sacroiliac Joint Radiofrequency Neurotomy Studies

\begin{tabular}{|c|c|c|c|c|}
\hline $\begin{array}{l}\text { Author, } \\
\text { Year }\end{array}$ & Type of RF & Diagnostic Criteria & $\begin{array}{l}\text { Follow- } \\
\text { Up } \\
\text { (Months) }\end{array}$ & Results \\
\hline $\begin{array}{l}\text { Buijs et al } \\
2004^{78}\end{array}$ & Unipolar & $>50 \%$ relief with single SIJB & 3 & $\begin{array}{l}24 \text { patients }(56 \%) \text { with the study reported at least } 50 \% \\
\text { pain relief. } 10 \text { patients ( } 23 \% \text { ) had complete pain relief. }\end{array}$ \\
\hline $\begin{array}{l}\text { Burnham } \\
\text { et al } 2007^{79}\end{array}$ & Bipolar & & $1,3,6,12$ & $\begin{array}{l}9 \text { patients were included in this pilot study. Median pain } \\
\text { score decreased from } 8 / 10 \text { to } 3.5 / 10 \text { at I and } 3 \text { months } \\
\text { and } 4.5 / 10 \text { at } 6 \text { and } 12 \text { months. The study showed } \\
\text { reductions of back and leg pain frequency and severity, and } \\
\text { analgesic intake. } 8 \text { of } 9 \text { subjects were satisfied overall. }\end{array}$ \\
\hline $\begin{array}{l}\text { Cheng et al } \\
2013^{80}\end{array}$ & $\begin{array}{l}\text { Cooled or } \\
\text { unipolar }\end{array}$ & $\geq 50 \%$ relief with each of two SIJBs & 6 & $\begin{array}{l}58 \text { patients underwent cooled RF technique and } 30 \\
\text { unipolar technique. At six-month follow-up, } 28 \text { of the } \\
\text { patients ( } 32 \% \text { ) had }>50 \% \text { pain relief with no significant } \\
\text { difference between either cooled or unipolar. }\end{array}$ \\
\hline $\begin{array}{l}\text { Cohen et al } \\
2003^{81}\end{array}$ & Unipolar & $80 \%$ relief SIJB, $50 \%$ after SLBBs & 9 & $\begin{array}{l}8 \text { of } 9 \text { patients }(89 \%) \text { reported }>50 \% \text { relief of pain and } \\
\text { two of the nine }(22 \%) \text { reported total pain relief. }\end{array}$ \\
\hline $\begin{array}{l}\text { Cohen et al } \\
2008^{73}\end{array}$ & $\begin{array}{l}\text { Cooled and } \\
\text { Unipolar }\end{array}$ & $\begin{array}{l}\geq 75 \% \text { relief with an intra-articular SIJI } \\
\text { with bupivacaine and steroid. }\end{array}$ & I, 3, 6 & $\begin{array}{l}\text { At I-, 3- and 6-months post-procedure, II, } 9 \text {, and } 8 \text { out of } \\
\text { I4 patients treated with active cooled RFN and } 7,6 \text { and } 4 \\
\text { out of II patients treated with unipolar RFN had at least } \\
50 \% \text { pain relief based on the NRS scale. Only } 2 \text { out of I4 } \\
\text { sham patients achieved treatment success at the one- } \\
\text { month follow-up, and none at } 3 \text { or } 6 \text { months. The authors } \\
\text { used SIJ injections, rather than sacral lateral branch blocks } \\
\text { as the diagnostic measure, which is considered a limitation } \\
\text { to this study. }\end{array}$ \\
\hline $\begin{array}{l}\text { Cohen et al } \\
2009^{82}\end{array}$ & $\begin{array}{l}\text { Cooled or } \\
\text { Unipolar }\end{array}$ & $\geq 50 \%$ relief with each of two SIJBs & 6 & $\begin{array}{l}40 \text { of } 77 \text { patients ( } 52 \% \text { ) reported }>50 \% \text { relief of pain at } 6 \\
\text { month follow-up. }\end{array}$ \\
\hline $\begin{array}{l}\text { Dutta et al } \\
2018^{76}\end{array}$ & Pulsed & $\begin{array}{l}\geq 80 \% \text { relief with an intra-articular SIJ } \\
\text { injection with a local anesthetic }\end{array}$ & $1,3,6$ & $\begin{array}{l}\text { At I, } 3 \text { and } 6 \text { months I5, I3, and I } 3 \text { out of I } 5 \text { patients had } \\
\text { a } \geq 50 \% \text { reduction in numerical pain score, a positive } \\
\text { Global Perceived Effect (GPE), and a } 5 \text {-point decrease in } \\
\text { ODI score. At } 3 \text { and } 6 \text { months, the mean NRS score was } \\
\text { higher in the IA steroid group, with statistical significance. } \\
\text { The results suggest that though IA steroid injections may } \\
\text { be effective, the use of PRF may be superior in overall } \\
\text { improvement and duration of pain relief. }\end{array}$ \\
\hline $\begin{array}{l}\text { Ferrante } \\
\text { et al } 2001^{68}\end{array}$ & Bipolar & Not specified & 6 & $\begin{array}{l}12 \text { of } 33 \text { patients ( } 36 \% \text { ) reported } \geq 50 \% \text { pain relief for } 6 \\
\text { months. }\end{array}$ \\
\hline $\begin{array}{l}\text { Ho et al } \\
2013^{83}\end{array}$ & Cooled & $\begin{array}{l}>50 \% \text { pain relief with SIJ steroid } \\
\text { injection }\end{array}$ & $\begin{array}{l}\mathrm{I}, 3,6,12, \\
24\end{array}$ & $\begin{array}{l}\text { I5 of } 20 \text { patients showed a significant reduction in pain } \\
\text { (reduction of at least } 3 \text { points on Numeric Rating Scale). } \\
\text { Mean for pain was reduced from a NRS of } 7.4 \pm 1.4 \text { to } 3.1 \\
\pm 2.5 \text {. Mean Patient Global Impression of Change was } \\
\text { "improved" (I.4 } \pm \text { I.5), and Global Perceived Effect was } \\
\text { reported to be positive in } 16 \text { patients at two year follow- } \\
\text { up. }\end{array}$ \\
\hline $\begin{array}{l}\text { Kapural et al } \\
2008^{84}\end{array}$ & Cooled & $>50 \%$ relief with each of two SIJBs & $3-4$ & $\begin{array}{l}\text { I3 of } 27 \text { patients ( } 48 \% \text { ) reported at least } 50 \% \text { pain } \\
\text { reduction at follow-up and three (I I\%) reported } \\
\text { complete relief. }\end{array}$ \\
\hline
\end{tabular}

(Continued) 
Table 6 (Continued).

\begin{tabular}{|c|c|c|c|c|}
\hline $\begin{array}{l}\text { Author, } \\
\text { Year }\end{array}$ & Type of RF & Diagnostic Criteria & $\begin{array}{l}\text { Follow- } \\
\text { Up } \\
\text { (Months) }\end{array}$ & Results \\
\hline $\begin{array}{l}\text { Karaman } \\
\text { et al } 2011^{85}\end{array}$ & Cooled & $>75 \%$ relief with each of two SIJBs & 6 & $\begin{array}{l}12 \text { of } 15 \text { patients }(80 \%) \text { reported at least } 50 \% \text { reduction in } \\
\text { pain scores. }\end{array}$ \\
\hline $\begin{array}{l}\text { Patel et al } \\
2012^{74} \text { and } \\
2016^{75}\end{array}$ & Cooled & $\geq 75 \%$ relief with each of two SIJBs & $3,6,9,12$ & $\begin{array}{l}\text { At } 3,6,9 \text {, and } 12 \text { months post-procedure } 16 / 34,13 / 27 \text {, } \\
20 / 25 \text {, and } 10 / 25 \text { had at least } 50 \% \text { pain relief based on the } \\
\text { NRS scale and either a } 10 \text {-point increase in SF-36BP or } \\
10 \text {-point decrease in ODI. At } 3 \text { months } 2 \text { of the } 17 \text { sham } \\
\text { patients achieved treatment success. } 16 \text { of the sham } \\
\text { patients then crossed over to cooled RFN. At I, 3, and } 6 \\
\text { months post-procedure for the cross-over group } 7,7 \text {, and } \\
6 \text { of the } 16 \text { subjects achieved treatment success. At } 12 \\
\text { months post-procedure, } 6 \text { achieved treatment success. }\end{array}$ \\
\hline $\begin{array}{l}\text { Schmidt et al } \\
2014^{86}\end{array}$ & $\begin{array}{l}\text { Unipolar } \\
\text { and Bipolar } \\
\text { (Simplicity) }\end{array}$ & $\begin{array}{l}>50 \% \text { pain relief with SIJ steroid } \\
\text { injection }\end{array}$ & I, 5, 6, 12 & $\begin{array}{l}\text { Out of the } 77 \text { radiofrequency treatments included, } 71.4 \% \\
(\mathrm{~N}=55) \text { reportedly had }>50 \% \text { pain relief. At } 6 \text { months, } \\
54.5 \% \text { of the treatments continued to have a successful } \\
\text { outcome. }\end{array}$ \\
\hline $\begin{array}{l}\text { Speldewinde } \\
\text { et al } 2011^{87}\end{array}$ & Unipolar & $>80 \%$ relief with each of two SIJBs & 2 & $\begin{array}{l}20 \text { patients were followed by phone } 6-36 \text { months after RF } \\
\text { treatment. Twelve patients of } 20(75 \%) \text { reported at least } \\
50 \% \text { relief for } 2 \text { months. Seven patients ( } 44 \%) \text { reported } \\
\text { having had complete relief. }\end{array}$ \\
\hline $\begin{array}{l}\text { Stelzer et al } \\
2013^{88}\end{array}$ & Cooled & $>50 \%$ relief with single SIJB & $>4$ & $\begin{array}{l}77 \text { of } 126(6 \mid \%) \text { of patients reported } \geq 50 \% \text { pain relief for } \\
>4 \text { months. }\end{array}$ \\
\hline $\begin{array}{l}\text { Yin et al } \\
2003^{89}\end{array}$ & Unipolar & $>50 \%$ relief with each of two SIJBs & 6 & $\begin{array}{l}9 \text { of } 14 \text { patients }(64 \%) \text { had }>50 \% \text { decrease in visual integer } \\
\text { pain score and } 36 \% \text { had complete relief. }\end{array}$ \\
\hline $\begin{array}{l}\text { Zheng et al } \\
2014^{77}\end{array}$ & Bipolar & $\begin{array}{l}\geq 80 \% \text { relief with an intra-articular SIJ } \\
\text { injection with } 40 \mathrm{mg} \text { Triamcinolone in } \\
0.5 \% \text { bupivacaine }\end{array}$ & 3,6 & $\begin{array}{l}\text { At } 3 \text { and } 6 \text { months post procedure, } 39 \text { and } 37 \text { (out of } 76 \\
\text { patients with ankylosing spondylitis) had at least } 20 \% \text { and } \\
\text { improvement of I unit (on a } 0-10 \text { scale). Pain reduction } \\
\text { found to be greater in bipolar RFN arm at } 12 \text { and } 24 \\
\text { weeks in comparison in the celecoxib arm, }(P<0.000 \text { I). } \\
\text { Bipolar RFN was also more effective in improving physical } \\
\text { function and spinal mobility ( } P<0.05 \text { ). The authors } \\
\text { concluded that RFN is an effective manner to treat SIJ } \\
\text { point in patients with ankylosing spondylitis. }\end{array}$ \\
\hline
\end{tabular}

peri-foraminal technique (Figure 6) was found to be an adequate alternative but requires multiple lesions surrounded in the lateral aspect of the S1, S2, S3 neural foramina.

\section{Best Practices Summary}

- Diagnosing SIJ pain consists of a physical examination including multiple provocative maneuvers (distraction, side thigh thrust, Gaenslen, compression and sacral thrust). The best predictive power is found with positive provocation utilizing 2 of 4 selected tests. If none of the six provocation tests reproduce pain symptoms, SIJ pathology may be ruled-out. Ober's and Patrick's tests are secondary options, though these have not been extensively studied.

- Prior to RF of the lateral sacral nerves, other possible etiologies must be ruled out by way of imaging. Radiographs may show degenerative changes and inflammation within the SIJ but are not diagnostic for SIJ pain. 


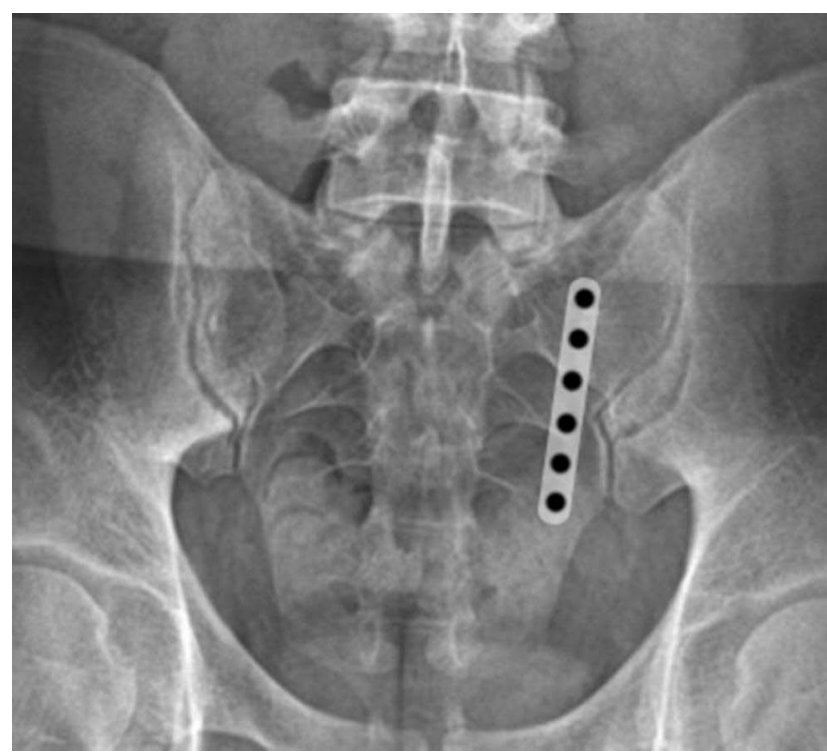

Figure 5 Radiofrequency cannulae placement for palisade technique.

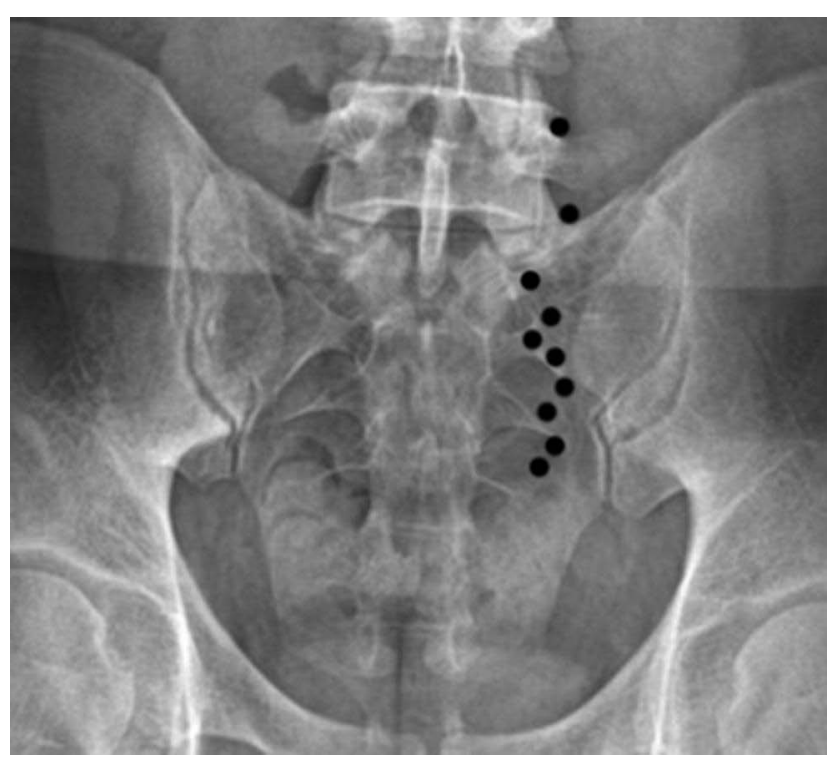

Figure 6 Radiofrequency cannulae placement for peri-foraminal technique.

- Contraindications for RFN include sacral fracture, tumor, radiculopathy, infection and coagulopathy.

- A diagnostic block for the lateral sacral branches is highly recommended prior to performing RF, even in cases when previous sacroiliac joint injection was performed. While limited evidence exists regarding diagnostic cutoff, recommendation is for $50 \%$ or greater reduction in pain prior to advancing to RF. Multisite and multi-depth technique is recommended to appropriately select RF candidates.
- The use of bipolar or cooled RFN is ideal to ensure that the lateral branches are captured with a larger sized lesion. Using a lateral x-ray view, place six (6) cannuale starting superior to $\mathrm{S} 1$ and stopping inferior to S3. Cannulae should be parallel to each other, spaced 10-12 $\mathrm{mm}$ from the next and perpendicular to the sacral surface.

- The use of monopolar RFN has been shown to be effective clinically, but multiple RF cannula passes or the use of periforaminal technique is recommended to create larger sized lesions.

- When using bipolar or monopolar RFN, temperature of 80 degrees Centigrade for 60-90 seconds per cycle is recommended.

- The use of a large strip lesion is able to capture most of the lateral branches with a more medial placement of the RF probe.

\section{Treatment Gaps \& Future Research}

The main limitation found within the literature is the heterogeneity of the studies involved. Most studies utilized intra-articular joint injections to select patients for sacral lateral branch RFN. As identified by Dreyfuss et al, the use of diagnostic nerve blocks in the posterior sacral nerve supply is more appropriate and prognostic for outcomes of RF. Not only is further research needed for the use of diagnostic sacral nerve blocks but also with neurotomy itself. Studies used conventional RF, pulsed RF, and cooled RF, with variable parameters and procedural times. The present literature suggests the clinical efficacy of unipolar, bipolar, cooled and pulsed RF; however, studies are limited and are of fair quality at best.

\section{Consensus Statement}

Lateral sacral branch radiofrequency neurotomy may be used for the treatment of posterior sacral ligament and joint pain following positive response to appropriately placed diagnostic blocks. GRADE II-1 B.

\section{Radiofrequency Neurotomy for Peripheral Joints}

Large joint RFN has been used predominantly to treat patients with end-stage osteoarthritis (OA). It is estimated that as many as 32 million Americans are affected by OA. ${ }^{91,92}$ Large joint RFN has been described for the treatment of hip pain, knee pain, and more recently, the 
shoulder pain. As the availability of RFN has evolved, so to have the applications. RFN can also be utilized for treating rheumatologic joint disease, post-arthroplasty pain, metastatic disease, osteonecrosis, and chronic infection. $^{93}$

The capsular and intra-articular innervation of large joints is complex. The afferent nerves often originate from multiple motor-sensory nerves, and there are variances in its procedural execution. Due to this complexity, it is imperative that the treating physician understands the regional anatomy of the target area in order to avoid complications.

\section{Current Available Evidence of Knee Joint Radiofrequency Neurotomy}

A multitude of studies, including randomized clinical trials (RCT) and meta-analyses, have examined the effectiveness of radiofrequency neurotomy of the knee (Table 7).

\section{Procedure Techniques}

Recent meticulous dissection studies, including those by both Tran et al and Fonkoue et al, have revealed evidence for both the use of classical and alternate targets for knee RFN. ${ }^{115-120}$ Tran et al, in two different cadaver studies demonstrated that the articular branches to the knee terminated in their respective quadrants with minimal overlap, though each quadrant could have multiple contributing nerves in addition to the classic superolateral (SL), superomedial (SM), and inferomedial (IM) genicular nerves. ${ }^{116}$ In a 2020 study, the authors used ultrasound-guided RF cannulae to target the classic SL, SM, and IM nerves and then dissected around the cannulae creating a threedimensional digitized model showing that classical landmarking can be effective for genicular RFN, though may not capture all the articular innervating branches of the knee. ${ }^{117}$ In 2019 and 2020, Fonkoue et al used dye and subsequent dissection in 21 and 14 cadavers, respectively, to identify the most effective landmark positions for fluoroscopy-guided genicular nerve blockade and RFN. The results demonstrated the increased effectiveness of revised targets that are, in general, more posterior in the knee than the classical landmarks. ${ }^{118-120}$

Traditionally, fluoroscopy has been used to guide needle placement for RFN, predominantly targeting the genicular nerves as their course along the periosteum (Figure 7). However, more recently ultrasound (US) has been shown to be an effective method of image guidance for RF knee procedures. A systematic review and meta-analysis on US

Table 7 Summary of Major Studies on RFN of Nerves That Supply the Knee

\begin{tabular}{|c|c|c|}
\hline Author, Year & Study Type & Results \\
\hline Bhatia et al $2016^{93}$ & $\begin{array}{l}\text { Systematic } \\
\text { review }\end{array}$ & $\begin{array}{l}\text { This review identified I } 3 \text { publications, representing } 329 \text { patients, which met criteria for inclusion. Of the } \\
\text { thirteen included studies, six represented conventional or cooled RFN treatments. }{ }^{93-98} \text { Conclusions } \\
\text { from these studies included a high rate of success in alleviating chronic pain of the knee joint from } 3 \text { to } 12 \\
\text { months, improvement in function, in the absence of serious adverse events. }\end{array}$ \\
\hline Choi et al $2011^{94}$ & $\begin{array}{l}\text { Randomized } \\
\text { control trial }\end{array}$ & $\begin{array}{l}38 \text { patients were randomized into RFN or sham RF. The RFN group had significantly lower pain scores } \\
\text { compared to control at } 4 \text { and } 12 \text { weeks, and functional improvement. (Note that this article was cited in } \\
\text { Bhatia et al 2016.) }\end{array}$ \\
\hline $\begin{array}{l}\text { Jamison and } \\
\text { Cohen } 2018^{99}\end{array}$ & $\begin{array}{l}\text { Literature } \\
\text { Review }\end{array}$ & $\begin{array}{l}\text { This review identified } 9 \text { relevant randomized or comparative clinical trials, representing } 592 \text { patients; two } \\
\text { studies previously reported in Bhatia et al, }{ }^{94,95} \text { and seven new trials. }{ }^{12,99-104} \text { Eight trials specifically } \\
\text { compared knee RFN to sham or other treatments such as steroid injections. One study examined intra- } \\
\text { articular pulsed RF. This review concluded that there was significant pain reduction and improvement in } \\
\text { function as measured time points from } 3 \text { to } 12 \text { months. Efficacy of diagnostic blocks was questionable. } \\
\text { Limitations to this review included considerable variation in the RF targets, technique, as well as selection } \\
\text { criteria. }\end{array}$ \\
\hline Hong et al $2019^{106}$ & Meta-analysis & $\begin{array}{l}\text { The review consisted of existing RCTs indexed on other databases outside of English-based indices (eg, } \\
\text { PubMed) previously not included, such as Chinese-based indices (eg, CNKI). This meta-analysis included } \\
4 \text { studies from the prior reviews and } 8 \text { new RCTs, }{ }^{105-114} \text { representing } 84 I \text { patients. All studies described } \\
\text { a control group. Seven studies examined RFN of the genicular nerves. Notably, this review excluded } \\
\text { patients that were status-post knee arthroplasty and arthroscopic surgery. Results showed decreased } \\
\text { pain scores at I week, I month, and } 3 \text { months. }\end{array}$ \\
\hline
\end{tabular}




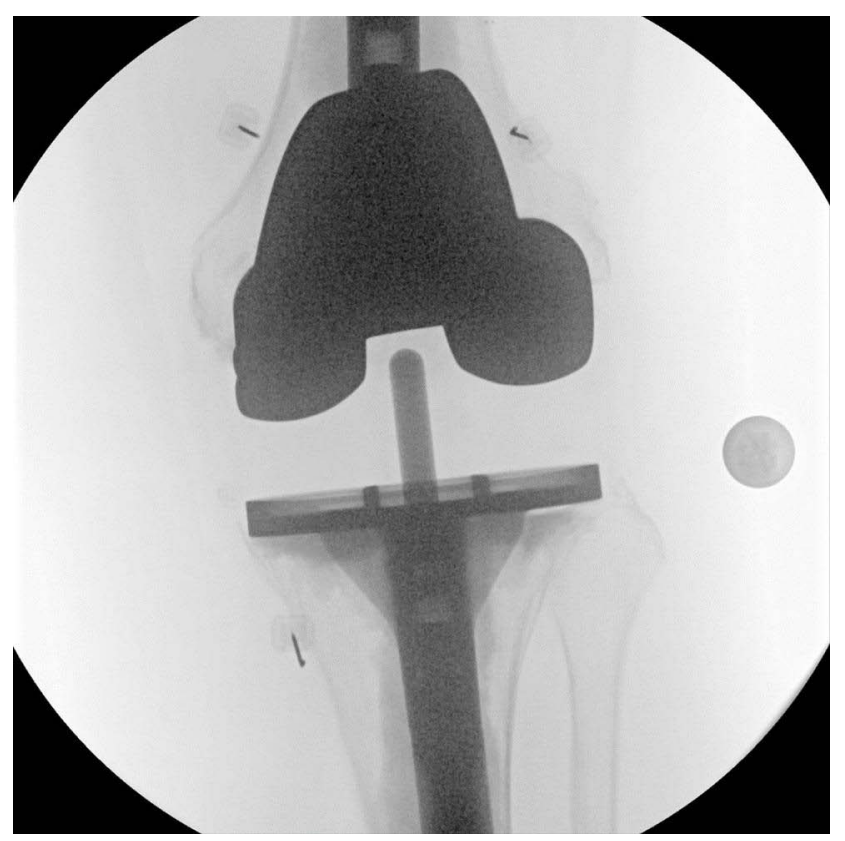

Figure 7 Anteroposterior (AP) view of the knee showing placement of radiofrequency needles along the trajectory of the superolateral, superomedial and the inferomedial genicular branches.

by Huang et al identified 8 publications with 256 patients in $2020{ }^{121}$ Three of the studies were RCTs and the remaining studies were prospective studies. Meta-analysis revealed US-guided RF knee procedures to result in a pooled mean difference in pain score of -4.2 (NRS scale) and a 23.2 improvement in WOMAC score compared to baseline before RF. An RCT by Sari et al directly compared USguided RF to fluoroscopic-guided RF, finding similar outcomes between the two modalities. ${ }^{122}$ Subgroup analysis found RFN of the genicular nerves as examined by four studies resulted in even greater pain reduction of a mean difference of -4.9 (compared to intra-articular modalities such as pulsed-RF). Adverse events reported were infrequent, mild and transient. Overall, US was found to be an effective, safe, non-ionizing, and technically achievable method for RF procedures of the knee, and that the genicular nerves are the preferred targets.

\section{Best Practice Summary}

- Radiofrequency ablative technologies for the nociceptive sensory innervation of the knee have been shown to be an effective therapy for chronic knee pain due to conditions, such as osteoarthritis and post-surgical pain.

- Utilization of RFN on the knee obviates a comprehensive knowledge and understanding of the anatomical innervation of the knee, experience with fluoroscopy or ultrasound, and knowledge regarding the principles surrounding RFN.

- Evidence-based parameters for electrode settings are the use of $70-80^{\circ} \mathrm{C}$ for $90-180$ seconds.

- In terms of technique, targeted genicular nerves for conventional and cooled RFN include the SM, SL, and IM nerves. Due to the variable anatomy of these branches, larger lesion sizes increase the likelihood of success.

- Pre-ablative diagnostic blocks with a low volume anesthetic may enable more accurate prognostication of the analgesic response to RFN.

- Avoiding unnecessary injury or inadvertent neurotomy of motor nerves, non-targeted sensory nerves, blood vessels, and other non-targeted anatomic structures is essential. Motor testing prior to ablation should be considered.

\section{Treatment Gaps \& Future Research}

In the past several years, there have been multiple studies, including high-quality RCTs, evaluating the efficacy of genicular RFN. These studies have included pain scales and validated measures of function at up to 12 months of follow-up. Further studies will enable the ideal use of this treatment modality. Further research topics should include the examination of demographic factors (eg BMI, gender, severity of OA), improve patient selection, the utility of prognostic blocks and repeat RFN. In general, the ideal timing of RFN in the setting of a multimodal management algorithm should also be established. ${ }^{122,123}$ Long-term outcomes, beyond a year, will also be important due to the chronic nature of the conditions typically treated with this modality.

\section{Consensus Statement}

Genicular nerve radiofrequency neurotomy may be used for the treatment of osteoarthritis related and post-surgical knee joint pain. GRADE II-1 B.

\section{Current Available Evidence of Hip Joint Radiofrequency Neurotomy}

The innervation of the hip was first studied and described in the mid-nineteenth century. German anatomist Rüdinger was a pioneer in describing the innervation of the large joints, including the shoulder, knee, and hip. ${ }^{124}$ Rüdinger's work laid the framework for surgical denervation 
techniques and interventional pain procedures. Further study and understanding of the articular branches of the hip was elucidated by Gardner in the 1940s. ${ }^{125}$ The evolution of RFN techniques has renewed the interest in hip pain treatment with RF techniques that maximize benefit while avoiding complications. Recent cadaveric dissections have shown notable anatomic variability with the location of articular branches from femoral (FN), obturator $(\mathrm{ON})$, and accessory obturator nerves. ${ }^{126}$

The anteromedial capsule of the hip is supplied by the branches of the obturator nerve, while the anterior capsule is innervated by branches of the femoral nerve. The sciatic nerve provides articular branches to the hip, posteriorly. Current ablative techniques focus on targeting the anterior hip. The accessory obturator nerve (AON) has been studied in cadaveric dissections and is present in a minority of individuals $(10-30 \%){ }^{127,128}$ The contribution of the AON (if present) can vary. The neurovascular bundle (femoral artery, vein, and nerve) is vulnerable to potential injury when targeting the obturator branches. Traditionally, this risk was mitigated by approaching the inferior aspect of the ischium from medial or lateral trajectories with the goal of passing underneath the bundle. The challenge with fluoroscopic guidance is that patients can have anatomic variations of the local neurovascular structures, which may result in bleeding and/or nerve injury. A thorough understanding of the anatomy of the articular branches, adjacent neurovascular structures, and needle approaches must be considered in order to optimize outcomes while decreasing adverse events.

\section{Current Available Evidence of Hip Radiofrequency Neurotomy}

The goal of hip RFN is to target major articular innervation to the anterior hip joint. RFN of hip articular branches was first described by Okada in 1981. ${ }^{128}$ He subsequently reported successful results in a series of 15 patients with neurotomy of the articular branches anteriorly (femoral and obturator) and posteriorly (sciatic). ${ }^{129}$ These early studies led to more robust investigation and interest in RFN for refractory hip pain. As hip RFN techniques evolved, neurotomy of both the femoral and articular branches became standard practice.

With the evolution of ultrasound technology and increased frequency of use in pain medicine, this modality is increasingly being used to increase accuracy and avoid complications. By no means does ultrasound replace fluoroscopy for hip RFN. Rather, it is often used in conjunction with fluoroscopy to aid in needle placement. Ultrasound may allow the proceduralist to avoid the femoral neurovascular bundle, decreasing the incidence of bleeding and nerve injury. These studies also show that it is imperative that motor testing is performed prior to neurotomy, as repositioning of cannula at the incisura acetabuli may be necessary to avoid the $\mathrm{ON}$ as it courses through the obturator foramen. Studies of hip RFN are summarized in Table 8.

\section{Procedure Technique}

Careful consideration and shared risk decision-making must be taken in regard to a patient's comorbidities and anticoagulation status. A paucity of data exists regarding best practices around anti-coagulation management for hip RFN. Many practitioners do not interrupt anticoagulants for diagnostic blocks and subsequent RFN, while others may stop these medications for the RFN portion or even both procedures. Larger cannula size may increase the risk of bleeding, particularly when targeting the ON branches, which run in close proximity to the femoral neurovascular bundle.

Patient body habitus and mobility are also important considerations. In the morbidly obese (BMI $>40$ ), it can be extremely difficult to place needles comfortably and easily. The patient must be able to tolerate being in a supine position for a prolonged period of time and have the ability to extend at the hip. If a patient is unable to tolerate these positions, RFN is likely to be challenging or not possible. At a minimum, fluoroscopy is needed to ensure proper identification of hip bony landmarks and to navigate challenging anatomy. Multiple studies have described a combined fluoroscopy and ultrasound technique that may improve safety and decrease the risk of vascular and/or nerve injury. ${ }^{132-135}$

There is a paucity of data when it comes to prognostic value of hip articular branch blocks. Despite this, it is recommended that patients undergo a diagnostic block before being considered for neurotomy. This is largely due to the multitude of pain generators that may cause pain in the hip area including tendinopathy, bursitis, and lumbosacral pathology. A minority of studies have used relief following intraarticular hip injections as selection criteria for RFN. ${ }^{130,136}$

Given the anatomic variability of articular branches, larger needles (21G or larger) are preferred. With conventional RFN, cannulae with a $10 \mathrm{~mm}$ active tip or larger is optimal. Cooled RFN is an alternative technique that may be 
Table 8 Summary of Studies on Hip RFN

\begin{tabular}{|c|c|c|}
\hline Author, Year & Study Type & Results \\
\hline $\begin{array}{l}\text { Short et al } \\
2018^{126}\end{array}$ & Research article & $\begin{array}{l}\text { Anatomical study of hip innervation in cadavers delineating the variable innervation of the anterior hip. } \\
\text { Thirteen hemi-pelvises were dissected and the contribution of the femoral (FN), obturator (ON), and } \\
\text { accessory obturator nerves were examined. The FN and ON contributed to the capsular innervation in } \\
\text { all specimens. The most consistent landmark was the inferomedial acetabulum (radiographic } \\
\text { "teardrop"). }\end{array}$ \\
\hline $\begin{array}{l}\text { Kawaguchi et al } \\
2001^{130}\end{array}$ & $\begin{array}{l}\text { Retrospective } \\
\text { cohort study }\end{array}$ & $\begin{array}{l}\text { A follow-up study looking at RFN feasibility focused primarily on the obturator articular branches, and } \\
\text { to a lesser extent the femoral articular branches. I } 4 \text { patients with various diagnoses leading to chronic } \\
\text { hip pain received either an intraarticular injection or obturator articular block with a local anesthetic. } \\
\text { Those with groin and thigh pain had only obturator articular neurotomy. Those who also had } \\
\text { trochanteric (lateral) pain also received a second neurotomy for the femoral articular branches. } 12 \\
\text { patients ( } 86 \% \text { ) reported at least } 50 \% \text { relief of pain for I to II months. }\end{array}$ \\
\hline $\begin{array}{l}\text { Rivera et al } \\
2012^{|3|}\end{array}$ & Clinical trial & $\begin{array}{l}\text { I } 8 \text { patients with hip pain ( } 16 \text { with } O A \text { and } 2 \text { with chronic post-surgical pain) received diagnostic articular } \\
\text { blocks with ropivacaine. To lesion the obturator sensory branches, a cannula was introduced just medial } \\
\text { to the femoral artery, below the inguinal ligament (medial approach) or } 3 \mathrm{~cm} \text { lateral to the femoral } \\
\text { artery (lateral approach), at a } 70^{\circ} \text { angle with the sagittal plane. The needle was advanced to the junction } \\
\text { between the ischium and the pubis corresponding to the incisura acetabuli. For the femoral branches, } \\
\text { the cannula was inserted via an anterolateral approach with the final position of the tip below anterior } \\
\text { inferior iliac spine along the superolateral hip. RFN was performed at each location at } 90^{\circ} \mathrm{C} \text { for } 90 \\
\text { seconds. Mean VAS scores were } 9.52 \text { and } 6.35 \text { before radiofrequency and at } 6 \text {-month follow-up, } \\
\text { representing approximately a } 38 \% \text { reduction. }\end{array}$ \\
\hline Kapural $2018^{132}$ & $\begin{array}{l}\text { Retrospective } \\
\text { cohort study }\end{array}$ & $\begin{array}{l}52 \text { patients undergoing cooled RFN for chronic hip pain with both fluoroscopy and ultrasound guidance. } \\
\text { Investigators were able to quantify the close proximity that exists between the } \mathrm{ON} \text { and the } \\
\text { neurovascular bundle. In } 2 \mathrm{I} \text { of the patients undergoing RFN, the distance was less than } \mathrm{I} \mathrm{cm} \text { (range } 0.5- \\
\mathrm{I} .9 \mathrm{~cm} \text {, with median } 0.8) \text {. The pain score improved went from } 7.6 \mathrm{I} \pm \mathrm{I} .2 \text { at baseline to } 2.25 \pm 1.4 \text { after } \\
\text { the RFN }(\mathrm{P}<0.0 \mathrm{I}) \text {. }\end{array}$ \\
\hline Naber $2019^{133}$ & Case series & $\begin{array}{l}\text { This case series of II patients undergoing cooled RFN of hip looked at the efficacy of cooled RFN with } \\
\text { combined ultrasound and fluoroscopic imaging in patients with avascular necrosis (AVN). Five patients } \\
\text { claimed more than } 50 \% \text { of pain relief. The average time interval of greater than } 50 \% \text { of pain relief from } \\
\text { the cooled RFN was } 70-250 \text { days. }\end{array}$ \\
\hline
\end{tabular}

superior given its increased volume of ablated tissue. Prior to neurotomy, we recommend that motor testing be performed to rule out proximity to the obturator or femoral nerves. Sensory testing can also be helpful in confirming proximity to the articular branches. Lastly, multiple neurotomy lesions of the ON and FN articular nerves should be considered given their unpredictable course.

\section{Best Practices Summary}

- At a minimum, fluoroscopy is necessary to ensure proper identification of hip bony landmarks and to navigate challenging anatomy. More investigation is required to determine the optimal use of ultrasound in hip denervation. Ultrasound is often used in conjunction with fluoroscopy for optimal needle placement.
- Patient body habitus and mobility are also important considerations. In the morbidly obese (BMI $>40)$, it can be extremely difficult to place needles comfortably and easily. Patients must be able to lie supine with the hip in neutral extension.

- Diagnostic blocks should be performed prior to neurotomy but data implying their prognostic value is limited.

- Neurotomy of both the femoral and articular branches has become standard practice using lateral to medial approaches with the patient in the supine position (Figure 8).

- Evidence best supports the use of conventional RF at 80 degrees for 90 seconds, although efficacy for cooled-RF has been shown in recent cohort and case series. 


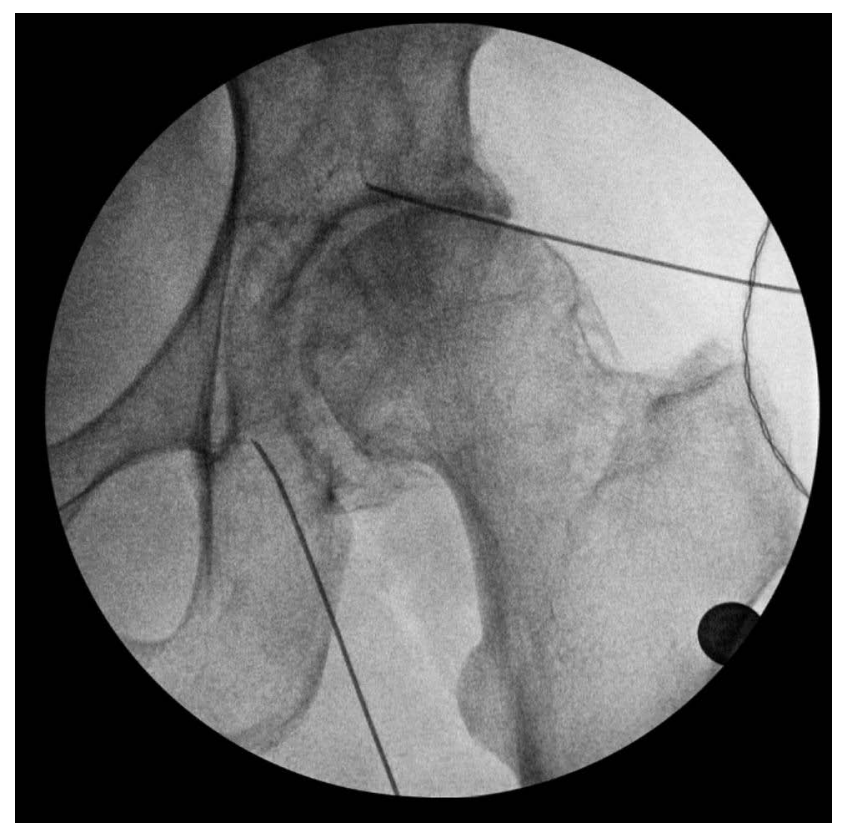

Figure 8 Fluoroscopy image of RFN cannulae placement targeting the articular branches of the $\mathrm{ON}$ and $\mathrm{FN}$. The articular branches of the $\mathrm{FN}$ are located inferior and medial to the anterior inferior iliac spine. The $\mathrm{ON}$ branches run just inferior to the incisura acetabuli. A lateral to medial approach is shown - a technique that aims to avoid the femoral neurovascular bundle. The yellow ovals denote neurotomy location.

- Larger lesion size is preferred given the anatomic variability of $\mathrm{ON}$ and $\mathrm{FN}$ articular branches. Multiple neurotomy lesions at each site will likely increase the procedure's success.

\section{Treatment Gaps \& Future Research}

Further investigation is needed to determine the optimal patient selection and protocol for improving outcomes. A review of the available literature found variable outcomes with regard to pain reduction ranging from 8 days to 3 years. ${ }^{137}$ Anatomical variations of the FN, ON, and AON are certainly factors in the success of neurotomy. Additionally, RFN modality (cooled vs traditional), number of lesions, and cannula size are also important.

\section{Consensus Statement}

Hip joint radiofrequency neurotomy targeting the obturator and femoral nerve branches may be used for the treatment of hip joint pain following diagnostic blocks. GRADE II-1 B.

\section{Occipital Nerve Radiofrequency Neurotomy}

Occipital RFN is used for the treatment of chronic occipital neuralgia $(\mathrm{ON})$ and posterior headache syndromes,

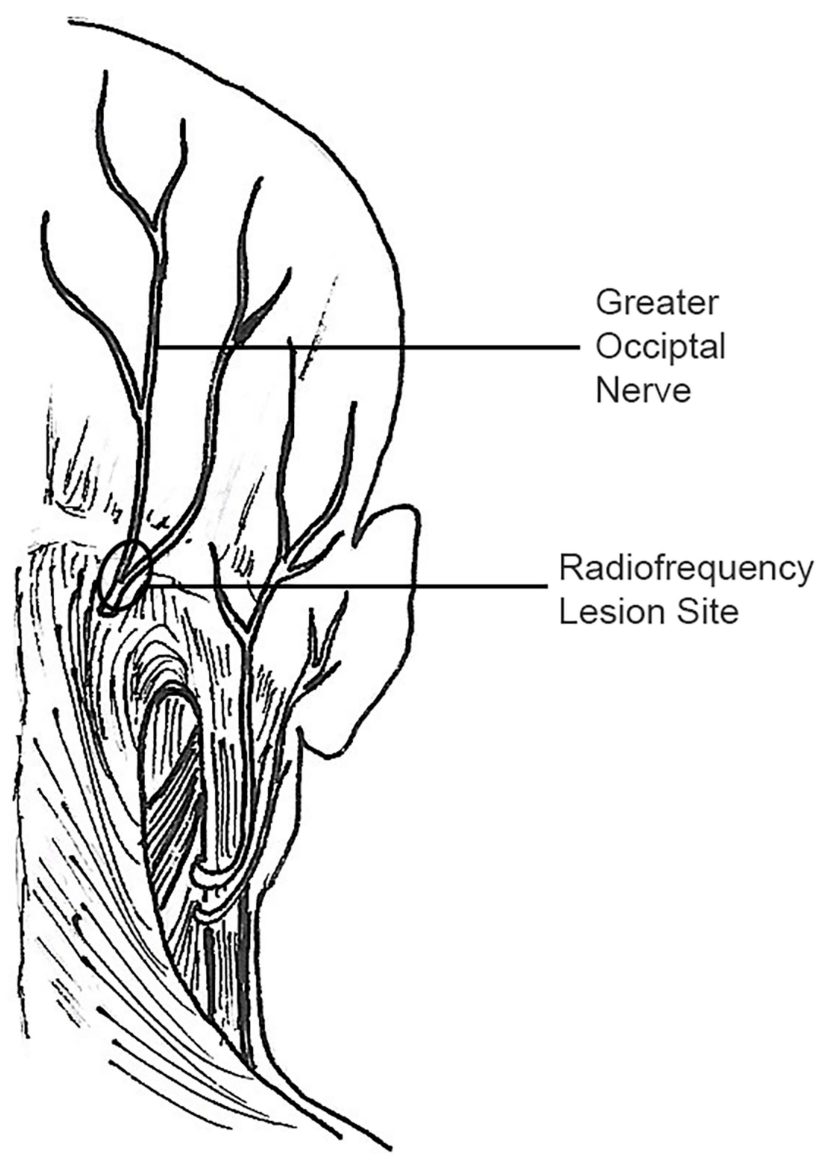

Figure 9 Illustration of optimal radiofrequency needle placement.

including refractory migraine. $\mathrm{ON}$ is considered to be rare, while also challenging to diagnosis and treat. Trauma, irritation, and entrapment of the greater (GON), lesser (LON) and/or third occipital (TON) nerves have been suggested as the etiology of ON, which may present as lancinating pain along the respective nerve distributions. Physical examination findings include occipital tenderness, palpable trigger points at the emergence of the greater occipital nerve or in the distribution of $\mathrm{C} 2$, and positive Tinel's sign over the occiput at the location of the greater and lesser occipital nerves. ${ }^{138}$ In lieu of diagnostic imaging findings, positive response to landmark guided or image-guided diagnostic block of the occipital nerves is confirmatory for the diagnosis, while the mainstay of treatment is considered to be a landmark or image guided corticosteroid injection. While RFN has been utilized in the treatment of $\mathrm{ON}$, it has not garnered universal acceptance. Various modalities of RFN have been described including CRF, PRF, and WCRF. 
Table 9 Studies of Occipital Nerve Radiofrequency Neurotomy

\begin{tabular}{|c|c|c|}
\hline Author, Year & Study Type & Results \\
\hline $\begin{array}{l}\text { Vanelderen } \\
\text { et al } 2010^{139}\end{array}$ & Clinical Study & $\begin{array}{l}\text { Prospective study in } 29 \text {-month period, } 19 \text { patients underwent PRF. Mean visual analog scale } \\
\text { and median Medication Quantification Scale scores declined by } 3.6(P=0.002) \text { and } 8(P= \\
0.006) \text {, respectively, at } 6 \text { months. } 52.6 \% \text { of patients reported a score of } 6 \text { (pain improved } \\
\text { substantially) or higher on the Likert scale. }\end{array}$ \\
\hline $\begin{array}{l}\text { Huang et al } \\
2012^{140}\end{array}$ & Clinical Study & $\begin{array}{l}\text { Retrospective study of } 102 \text { consecutive ON patients treated with PRF of the greater and/ } \\
\text { or lesser occipital nerve. } 51 \% \text { patients reported } \geq 50 \% \text { pain relief and satisfaction with } \\
\text { treatment for at least } 3 \text { months duration. Nerves treated were GON, LON or both GON } \\
\text { and LON. Patients with lower volume diagnostic blocks and multiple lesions of PRF did } \\
\text { significantly better. }\end{array}$ \\
\hline $\begin{array}{l}\text { Choi et al } \\
2012^{|4|}\end{array}$ & Clinical Study & $\begin{array}{l}10 \text { patients treated with PRF with mean follow-up of } 7.5 \text { months show average } 6.1 \text { point } \\
\text { reduction in VAS score. }\end{array}$ \\
\hline $\begin{array}{l}\text { Vanderhoek } \\
\text { et al } 2013^{142}\end{array}$ & Case series & 2 patients treated successfully with ultrasound guided blocks and PRF \\
\hline $\begin{array}{l}\text { Vu et al } \\
2014^{143}\end{array}$ & Case Report & $\begin{array}{l}35 \text { yo female with benefit from WCRF of the bilateral GON, reporting } 75 \% \text { reduction in } \\
\text { pain. }\end{array}$ \\
\hline $\begin{array}{l}\text { Cohen et al } \\
2015^{144}\end{array}$ & $\begin{array}{l}\text { Multicenter randomized double- } \\
\text { blind sham controlled RCT }\end{array}$ & $\begin{array}{l}\text { Study compared effectiveness of occipital nerve block with steroid versus PRF. 8I } \\
\text { participants with ON or migraine with occipital nerve tenderness. PRF was carried out } \\
\text { with three cycles at I } 20 \text { seconds each. The PRF arm showed significant improvements over } \\
\text { control at } 6 \text { weeks with sustained benefits seen at } 6 \text { months. }\end{array}$ \\
\hline $\begin{array}{l}\text { Finiels et al } \\
2016^{145}\end{array}$ & Clinical Study & $\begin{array}{l}\text { Retrospective III patients with positive diagnostic blocks, } 78 \text { of whom treated with RFN, } \\
\text { remainder treated with botulinum toxin injection or occipital nerve stimulation. } 89.4 \% \text { of } \\
\text { patients treated with RFN showed "good" and "very good" results out to } 6 \text { months, } \\
\text { compared to } 80 \% \text { in the other treatment groups. }\end{array}$ \\
\hline $\begin{array}{l}\text { Hoffman et al } \\
2018^{146}\end{array}$ & Clinical Study & $\begin{array}{l}\text { A retrospective study of } 46 \text { patients who underwent CRF at } 80 \text { degrees } C \text { for } I 80 \text { seconds } \\
\text { after sensory stimulation by landmark-based technique. A significant difference reduction in } \\
\text { pain scores }(6.7 \text { vs } 2.7 \text {, respectively; } P<0.00 \text { I), equating to a mean reduction in pain scores } \\
\text { I-month post-procedure of } 4.0 \pm 3.3 \text {. The mean patient-defined percent pain relief was } \\
76.3 \% \pm 25.0 \% \text {. The mean patient-reported length of relief was } 6.5 \pm 5 . I \text { months. }\end{array}$ \\
\hline
\end{tabular}

\section{Current Available Evidence of Occipital Nerve Radiofrequency Neurotomy}

Recent publications are summarized in Table 9.

\section{Procedure Techniques}

Published studies describe a myriad of techniques for occipital nerve RFN. Most commonly landmark-based and fluoroscopic techniques are described, with scant literature describing the utilization of ultrasound. The most robust techniques describe multiple needles targeting the GON and LON utilizing sensory stimulation relying on patient feedback for localization. The recommendation to place the needle in parallel line as opposed to perpendicular plane is in keeping with recommendations at other anatomic sites. Multiple cycles of PRF at 42 degrees Celsius and single lesions of CRF have been described.

\section{Best Practices Summary}

- Use of occipital nerve RFN is primarily for symptoms of ON causing posterior head pain and has also been described for use in migraine syndromes with occipital tenderness

- Implementation of the International Headache Society diagnostic criteria for $\mathrm{ON}$ is standard practice

- Diagnostic blockade of the occipital nerves should precede use of RFN

- Prior to RFN of the occipital nerves, other possible etiologies should be ruled out by way of either magnetic resonance imaging (MRI) and/or computerized tomography (CT) imaging. Imaging is not itself a diagnostic for ON

- Evidence best supports the use of PRFN over other RFN options. Time settings for lesion creation range 
from a single lesion at 90 seconds to up to three lesions for 120 seconds. Further studies are necessary to compare procedural techniques.

- Six months of pain relief has been documented in several studies. Longer follow-up periods are needed to put forth recommendations for repeat sessions of RFN in successfully treated patients.

\section{Treatment Gaps}

Further research is needed to best understand the optimal protocol for diagnostic block, the use of image guidance for occipital RFN, the optimal procedure techniques, and timetable for repeat procedures in successfully treated patients.

\section{Future Research}

Research and evidence gaps exist for occipital nerve pulsed radiofrequency (PRF). PRF allows for the application of radiofrequency current at lower temperatures, thereby minimizing the damage to surrounding tissue, nerve or vasculature. They may be the preferred technique given the superficial location of the occipital nerves. Further research on PRF is needed to determine the efficacy and safety of this treatment modality, and how it compares to CRF and WCRF. Although several studies have demonstrated the efficacy of both continuous and pulsed RF within the range of 6 weeks to 6 months more evidence is clearly needed.

\section{Consensus Statement}

Occipital neurotomy may be selectively offered for the treatment of occipital neuralgia pain when greater or lesser nerves have been identified as the etiology of pain via diagnostic blocks. GRADE II-2 C.

\section{Conclusion}

The use of radiofrequency ablation to treat pain is an established therapy that continues to evolve. This best practice document gives an evaluation as to the current evidence and recommendations. Going forward, these recommendations will be updated as new data is produced by either high-level studies or from large registries. Future guidelines will be modified as evidence is built, innovations arrive at the technology, and new ideas are presented to continue to improve patient safety and efficacy.

\section{Acknowledgments}

The authors would like to thank Abbott Laboratories for a generous educational grant for the development of this and other Best Practices Guidelines for interventional procedures currently relevant to our field. This manuscript was developed through a collaboration with the American Society of Pain \& Neuroscience (ASPN) and its leadership. The authors are grateful for their tireless support and guidance. Illustrations were used with permission from Min A. Lee.

\section{Disclosure}

Dr David W Lee reports grants from Abbott, during the conduct of the study; is a member of speakers Bureau for Abbott Neuromodulation, outside the submitted work. Dr Scott Pritzlaff reports personal fees from Nalu Medical, personal fees from EBT Medical, personal fees from SPR Therapeutics, outside the submitted work. Dr Jonathan M Hagedorn reports personal fees from Abbott, personal fees from Boston Scientific, personal fees from Nevro, personal fees from Speranza Therapeutics, outside the submitted work. Dr Jordan Tate reports personal fees from Abbott. Dr Dawood Sayed reports personal fees from Abbott, personal fees from Medtronic, personal fees from Nevro, PainTeq, Spr, and Vertos, during the conduct of the study. Dr Timothy R Deer reports personal fees from Abbott; also his institution research received funding from Avanos, outside the submitted work. The authors report no other conflicts of interest in this work.

\section{References}

1. Krischner M. Zur elektrochirurgie[For electrosurgery]. Arch Klin Chir. 1931;147:761. German.

2. Bogduk N, Long DM. The anatomy of the so-called "articular nerves" and their relationship to facet denervation in the treatment of low-back pain. J Neurosurg. 1979;51(2):172-177. doi:10.3171/jns.1979.51.2.0172

3. van Kleef M, Barendse GA, Dingemans WA, et al. Effects of producing a radiofrequency lesion adjacent to the dorsal root ganglion in patients with thoracic segmental pain. Clin J Pain. 1995;11 (4):325-332. doi:10.1097/00002508-199512000-00010

4. Malik A, Simopolous T, Elkersh M, Aner M, Bajwa ZH. Percutaneous radiofrequency lesioning of sensory branches of the obturator and femoral nerves for the treatment of non-operable hip pain. Pain Physician. 2003;6(4):499-502. doi:10.36076/ppj.2003/6/499

5. Geurts JW, van Wijk RM, Wynne HJ, et al. Radiofrequency lesioning of dorsal root ganglia for chronic lumbosacral radicular pain: a randomised, double-blind, controlled trial. Lancet. 2003;361 (9351):21-26. doi:10.1016/S0140-6736(03)12115-0

6. Ahadian FM. Pulsed radiofrequency neurotomy: advances in pain medicine. Curr Pain Headache Rep. 2004;8(1):34-40. doi:10.1007/ s11916-004-0038-4

7. Byrd D, Mackey S. Pulsed radiofrequency for chronic pain. Curr Pain Headache Rep. 2008;12(1):37-41. doi:10.1007/s11916-008-0008-3

8. Cosman ER. A comment on the history of the pulsed radiofrequency technique for pain therapy. Anesthesiology. 2005;103(6):1312;author reply 1313-1314. doi:10.1097/00000542-200512000-00028

9. Sluijter ME. Pulsed radiofrequency. Anesthesiology. 2005;103 (6):1313; author reply 1313-1314. doi:10.1097/00000542-20051200000029 
10. Sluijter ME, Cosman E, Rittman W, et al. The effect of pulsed radiofrequency fields applied to the dorsal root ganglion. Pain Clin. 1998;11:109-117.

11. Schiltenwolf M, Fischer C, Choi WJ, et al. Radiofrequency treatment relieves chronic knee osteoarthritis pain: a double-blind randomized controlled trial. Pain. 2011;152:481-487. doi:10.1016/j.pain.2010.09.029

12. Davis T, Loudermilk E, DePalma M, et al. Prospective, multicenter, randomized, crossover clinical trial comparing the safety and effectiveness of cooled radiofrequency ablation with corticosteroid injection in the management of knee pain from osteoarthritis. Reg Anesth Pain Med. 2018;43(1):84-91. doi:10.1097/AAP.0000000000000690

13. Hunter C, Davis T, Loudermilk E, Kapural L, DePalma M. Cooled radiofrequency ablation treatment of the genicular nerves in the treatment of osteoarthritic knee pain: 18- and 24-month results. Pain Pract. 2020;20(3):238-246. doi:10.1111/papr.12844

14. Hamer JF, Purath TA. Response of cervicogenic headaches and occipital neuralgia to radiofrequency ablation of the $\mathrm{C} 2$ dorsal root ganglion and/or third occipital nerve. Headache. 2014;54 (3):500-510. doi:10.1111/head.12295

15. Hechelhammer L, Pfirmann CWA, Zanetti M, et al. Imaging findings predicting the outcome of cervical facet joint blocks. Eur Radiol. 2007;17:959-964. doi:10.1007/s00330-006-0379-y

16. Cohen SP, Strassels SA, Kurihara C, et al. Randomized study assessing the accuracy of cervical facet joint nerve (medial branch) blocks using different injectate volumes. Anesthesiology. 2010;112(1):144-152. doi:10.1097/ALN.0b013e3181c38a82

17. Lord SM, Barnsley L, Bogduk N. Percutaneous radiofrequency neurotomy in the treatment of cervical zygapophysial joint pain: a caution. Neurosurgery. 1995;36(4):732-739. doi:10.1227/ 00006123-199504000-00014

18. Lord SM, Barnsley L, Wallis BJ, McDonald GJ, Bogduk N. Percutaneous radio-frequency neurotomy for chronic cervical zygapophyseal-joint pain. $N \quad$ Engl $\quad J \quad$ Med. 1996;335 (23):1721-1726. doi:10.1056/NEJM199612053352302

19. Shin WR, Kim HI, Shin DG, Shin DA. Radiofrequency neurotomy of cervical medial branches for chronic cervicobrachialgia. $J$ Korean Med Sci. 2006;21(1):119-125. doi:10.3346/ jkms.2006.21.1.119

20. Sapir DA, Gorup JM. Radiofrequency medial branch neurotomy in litigant and nonlitigant patients with cervical whiplash: a prospective study. Spine (Phila Pa 1976). 2001;26(12):E268E273. doi:10.1097/00007632-200106150-00016

21. McDonald GJ, Lord SM, Bogduk N. Long-term follow-up of patients treated with cervical radiofrequency neurotomy for chronic neck pain. Neurosurgery. 1999;45(1):61-67; discussion 67-68. doi:10.1097/00006123-199907000-00015

22. MacVicar J, Borowczyk JM, MacVicar AM, Loughnan BM, Bogduk N. Cervical medial branch radiofrequency neurotomy in New Zealand. Pain Med. 2012;13(5):647-654. doi:10.1111/ j.1526-4637.2012.01351.x

23. Barnsley L. Percutaneous radiofrequency neurotomy for chronic neck pain: outcomes in a series of consecutive patients. Pain Med. 2005;6(4):282-286. doi:10.1111/j.1526-4637.2005.00047.x

24. Spine Intervention Society. Cervical medial branch thermal radiofrequency neurotomy. In: Bogduk N editor. Practice Guidelines: Spinal Diagnostic and Treatment Procedures. 2nd ed. San Francisco: International Spine Intervention Society; 2013:165-217.

25. Engel A, Rappard G, King W, Kennedy DJ; Standards Division of the International Spine Intervention Society. The effectiveness and risks of fluoroscopically-guided cervical medial branch thermal radiofrequency neurotomy: a systematic review with comprehensive analysis of the published data. Pain Med. 2016;17 (4):658-669. doi:10.1111/pme.12928
26. Husted DS, Orton D, Schofferman J, Kine G. Effectiveness of repeated radiofrequency neurotomy for cervical facet joint pain. J Spinal Disord Tech. 2008;21(6):406-408. doi:10.1097/ BSD.0b013e318158971f

27. Manchikanti KN, Atluri S, Singh V, Geffert S, Sehgal N, Falco FJE. An update of evaluation of therapeutic thoracic facet joint interventions. Pain Physician. 2012;15:E463-E481.

28. Joo YC, Park JY, Kim KH. Comparison of alcohol ablation with repeated thermal radiofrequency ablation in medial branch neurotomy for the treatment of recurrent thoracolumbar facet joint pain. J Anesth. 2013;27:390-395. doi:10.1007/s00540-012-1525-0

29. Chang MC. Effect of pulsed radiofrequency treatment on the thoracic medial branch for managing chronic thoracic facet joint pain refractory to medial branch block with local anesthetics. World Neurosurg. 2018;111:e644-e648. doi:10.1016/j.wneu.2017.12.141

30. Rohof O, Chen CK. The response to radiofrequency neurotomy of medial branches including a bipolar system for thoracic facet joints. Scand J Pain. 2018;18(4):747-749. doi:10.1515/sjpain2018-0048

31. Gungor S, Candan B. The efficacy and safety of cooled-radiofrequency neurotomy in the treatment of chronic thoracic facet (zygapophyseal) joint pain: a retrospective study. Medicine (Baltimore). 2020;99(14):E19711. doi:10.1097/ MD.0000000000019711

32. International Spine Intervention Society. Lumbar medial branch blocks. In: Bogduk $\mathrm{N}$ editor. Practice Guidelines for Spinal Diagnostic and Treatment Procedures. 2nd ed. San Francisco: International Spine Intervention Society; 2013:457-488.

33. Manchikanti L, Hirsch JA, Pampati V, Boswell MV. Utilization of facet joint and sacroiliac joint interventions in medicare population from 2000 to 2014: explosive growth continues! Curr Pain Headache Rep. 2016;20(10):58. doi:10.1007/s11916-016-0588-2

34. Cohen SP, Bhaskar A, Bhatia A, et al. Consensus practice guidelines on interventions for lumbar facet joint pain from a multispecialty, international working group. Reg Anesth Pain Med. 2020;45(6):424-467.

35. Starr JB, Gold L, McCormick Z, et al. Trends in lumbar radiofrequency ablation utilization from 2007 to 2016. Spine J. 2019;19(6):1019-1028. doi:10.1016/j.spinee.2019.01.001

36. Kalichman L, Li L, Kim DH, et al. Facet joint osteoarthritis and low back pain in the community-based population. Spine. 2008;33(23):2560. doi:10.1097/BRS.0b013e318184ef95

37. Ko S, Vaccaro AR, Lee $S$, et al. The prevalence of lumbar spine facet joint osteoarthritis and its association with low back pain in selected Korean populations. Clin Orthop Surg. 2014;6:385-391. doi:10.4055/cios.2014.6.4.385

38. Sharahili HH, Waheed KB, Alaliwi HA. Facet joint injections in patients with low back pains and facet arthropathies-our experience. J Evol Med Dent Sci. 2020;9(42):3107-3112. doi:10.14260/ jemds/2020/682

39. Kavita N, Kimberly A, Manchikanti L. Age-related prevalence of facet-joint involvement in chronic neck and low back pain. Pain Physician. 2008;11(1):67-75.

40. Manchikanti L, Soin A. Trends of expenditures and utilization of facet joint interventions in fee-for-service (FFS) Medicare population from 2009-2018. Pain Physician. 2020;23:S129-S147. doi:10.36076/ppj.2020/23/S129

41. Petersen T, Laslett M, Juhl C. Clinical classification in low back pain: best-evidence diagnostic rules based on systematic reviews. BMC Musculoskelet Disord. 2017;18:188. doi:10.1186/s12891017-1549-6

42. Manchikanti L, Kaye A, Soin A. Comprehensive evidence-based guidelines for facet joint interventions in the management of chronic spinal pain: American Society of Interventional Pain Physicians (ASIPP) guidelines. Pain Physician. 2020;23:S1S127. doi:10.36076/ppj.2020/23/S1 
43. Cohen SP, Hurley RW, Christo PJ, et al. Clinical predictors of success and failure for lumbar facet radiofrequency denervation. Clin J Pain. 2007;23:45-52. doi:10.1097/01. ajp.0000210941.04182.ea

44. Streitberger K, Müller T, Eichenberger U, et al. Factors determining the success of 80 radiofrequency denervation in lumbar facet joint pain: a prospective study. Eur Spine J. 2011;20:2160-2165. doi:10.1007/s00586-011-1891-6

45. Conger A, Burnham T, Salazar F, et al. The effectiveness of radiofrequency ablation 81 of medial branch nerves for chronic lumbar facet joint syndrome in patients selected by guideline-concordant dual comparative medial branch blocks. Pain Med. 2019; 21(5):902-909.

46. Cohen SP, Doshi TL, Kurihara C, et al. Nonorganic signs and their association with interventional treatment outcomes for low back pain. Anesth Analg. 2020; 132(3):639-651.

47. International Spine Intervention Society. Lumbar medial branch thermal neurotomy. In: Bogduk N editor. Practice Guidelines for Spinal Diagnostic and Treatment Procedures. 2nd ed. San Francisco: International Spine Intervention Society; 2013:514-522.

48. Lee $\mathrm{C}-\mathrm{H}$, Chung $\mathrm{CK}$, Kim $\mathrm{CH}$. The efficacy of conventional radiofrequency denervation in patients with chronic low back pain originating from the facet joints: a meta- analysis of randomized controlled trials. Spine J. 2017;17:1770-1780. doi:10.1016/j.spinee.2017.05.006

49. Shih CL, Shen PC, Lu CC, et al. A comparison of efficacy among different radiofrequency ablation techniques for the treatment of lumbar facet joint and sacroiliac joint pain: a systematic review and meta-analysis. Clin Neurol Neurosurg. 2020;195:105854. doi:10.1016/j.clineuro.2020.105854

50. Maas ET, Ostelo RW, Niemisto L, et al. Radiofrequency denervation for chronic low back pain. Cochrane Database Syst Rev. 2015;10:CD008572.

51. Poetscher AW, Gentil AF, Lenza M, Ferretti M. Radiofrequency denervation for facet joint low back pain: a systematic review. Spine (Phila Pa 1976). 2014;39(14):E842-E849. doi:10.1097/ BRS.0000000000000337

52. Boswell MV, Manchikanti L, Kaye AD, et al. A best-evidence systematic appraisal of the diagnostic accuracy and utility of facet (zygapophysial) joint injections in chronic spinal pain. Pain Physician. 2015;18(4):E497-E533. doi:10.36076/ppj.2015/18/ E497

53. Falco FJ, Manchikanti L, Datta S, et al. An update of the effectiveness of therapeutic lumbar facet joint interventions. Pain Physician. 2012;15(6):E909-E953. doi:10.36076/ppj.2012/15/ E909

54. Juch JNS, Maas ET, Ostelo RWJG, et al. Effect of radiofrequency denervation on pain intensity among patients with chronic low back pain: the mint randomized clinical trials. JAMA. 2017;318:68-81. doi:10.1001/jama.2017.7918

55. Van Tilburg CWJ, Stronks DL, Groeneweg JG, et al. Randomized sham-controlled double-blind multicentre clinical trial to ascertain the effect of percutaneous radiofrequency treatment for lumbar facet joint pain. Bone Joint J. 2016;98- B:1526-1533. doi:10.1302/0301-620X.98B11.BJJ-2016-0379.R2

56. Cohen SP, Doshi TL, Constantinescu OC, et al. Effectiveness of lumbar facet joint blocks and their predictive value before radiofrequency denervation: the facet treatment study (FACTS). Anesthesiology. 2018;129:517-535. doi:10.1097/ ALN.0000000000002274

57. van Kuijk SMJ, van Zundert J, Hans G, et al. Flawed study design and incorrect presentation of data negatively impact potentially useful interventional treatments for patients with low back pain: a critical review of JAMA 's MinT study. Pain Pract. 2018;18:292-295. doi:10.1111/papr.12673
58. Conger A, Burnham T, Salazar F, et al. The effectiveness of radiofrequency ablation 81 of medial branch nerves for chronic lumbar facet joint syndrome in patients selected by guideline-concordant dual comparative medial branch blocks. Pain Med. 2019;pii:82 pnz248.

59. Tekin I, Mirzai H, Ok G, et al. A comparison of conventional and pulsed radiofrequency denervation in the treatment of chronic facet joint pain. Clin J Pain. 2007;23:524-529. doi:10.1097/ AJP.0b013e318074c99c

60. Rees WES. Multiple bilateral subcutaneous rhizolysis of segmental nerves in the treatment of the intervertebral disc syndrome. Ann Gen Prac. 1971;26:126-127.

61. Bogduk N, Long DM. Percutaneous lumbar medial branch neurotomy: a modification of facet denervation. Spine. 1980;5:193-200. doi:10.1097/00007632-198003000-00015

62. Loh JT, Nicol AL, Elashoff D, et al. Efficacy of needle-placement technique in radiofrequency ablation for treatment of lumbar facet arthropathy. J Pain Res. 2015;8:687-694.

63. Cheng J, Gutenberg LV, Dalton JE. Comparative long-term outcomes of lateral versus posterior approach to cervical facet medial branch radiofrequency ablation [abstract \#179]. Pain Med. 2013;14:586.

64. Cohen SP, Strassels SA, Kurihara C, et al. Does sensory stimulation threshold affect lumbar facet radiofrequency denervation outcomes? A prospective clinical correlational study. Anesth Analg. 2011;113:1233-1241. doi:10.1213/ ANE.0b013e31822dd379

65. Koh JC, Kim DH, Lee YW, et al. Relationship between paravertebral muscle twitching and long-term effects of radiofrequency medial branch neurotomy. Korean J Pain. 2017;30:296-303. doi:10.3344/kjp.2017.30.4.296

66. Laslett M, Aprill CN, McDonald B, Young SB. Diagnosis of sacroiliac joint pain: validity of individual provocation tests and composites of tests. Man Ther. 2005;10(3):207-218. doi:10.1016/ j.math.2005.01.003

67. Jung MW, Schellhas K, Johnson B. Use of diagnostic injections to evaluate sacroiliac joint pain. Int J Spine Surg. 2020;14 (Suppl1):30-34. doi:10.14444/6081

68. Ferrante FM, King LF, Roche EA, et al. Radiofrequency sacroiliac joint denervation for sacroiliac syndrome. Reg Anesth Pain Med. 2001;26(2):137-142. doi:10.1053/rapm.2001.21739

69. Egund N, Jurik AG. Anatomy and histology of the sacroiliac joints. Semin Musculoskelet Radiol. 2014;18(3):332-339. doi:10.1055/s-0034-1375574

70. Cox $\mathrm{M}, \mathrm{Ng} \mathrm{G}$, Mashriqi F, et al. Innervation of the anterior sacroiliac joint. World Neurosurg. 2017;107:750-752. doi:10.1016/j.wneu.2017.08.062

71. Forst SL, Wheeler MT, Fortin JD, Vilensky JA. The sacroiliac joint: anatomy, physiology and clinical significance. Pain Physician. 2006;9(1):61-67.

72. Dreyfuss P, Henning T, Malladi N, Goldstein B, Bogduk N. The ability of multi-site, multi-depth sacral lateral branch blocks to anesthetize the sacroiliac joint complex. Pain Med. 2009;10:679-688. doi:10.1111/j.1526-4637.2009.00631.x

73. Cohen SP, Hurley RW, Buckenmaier CC, et al. Randomized placebo-controlled study evaluating lateral branch radiofrequency denervation for sacroiliac joint pain. Anesthesiology. 2008;109:279-288. doi:10.1097/ALN.0b013e31817f4c7c

74. Patel N, Gross A, Brown L, Gekht G. A randomized, placebo-controlled study to assess the efficacy of lateral branch neurotomy for chronic sacroiliac joint pain. Pain Med. 2012;13 (3):383-398. doi:10.1111/j.1526-4637.2012.01328.x

75. Patel N. Twelve-month follow-up of a randomized trial assessing cooled radiofrequency denervation as a treatment for sacroiliac region pain. Pain Pract. 2016;16(2):154-167. doi:10.1111/ papr.12269 
76. Dutta K, Dey S, Bhattacharyya P, Agarwal S, Dev P. Comparison of efficacy of lateral branch pulsed radiofrequency denervation and intraarticular depot methylprednisolone injection for sacroiliac joint pain. Pain Physician. 2018;21(5):489-496.

77. Zheng Y, Gu M, Shi D, Li M, Ye L, Wang X. Tomography-guided palisade sacroiliac joint radiofrequency neurotomy versus celecoxib for ankylosing spondylitis: a open-label, randomized, and controlled trial. Rheumatol Int. 2014;34(9):1195-1202. doi:10.1007/s00296-014-2959-5

78. Buijs EJ, Kamphuis ET, Groen GJ. Radiofrequency treatment of sacroiliac joint-related pain aimed at the first three sacral dorsal rami: a minimal approach. Pain Clin. 2004;16(2):139-146. doi:10.1163/156856904774134334

79. Burnham RS, Yasui Y. An alternate method of radiofrequency neurotomy of the sacroiliac joint: a pilot study of the effect on pain, function, and satisfaction. Reg Anesth Pain Med. 2007;32(1):12-19.

80. Cheng J, Pope JE, Dalton JE, Cheng O, Bensitel A. Comparative outcomes of cooled versus traditional radiofrequency ablation of the lateral branches for sacroiliac joint pain. Clin J Pain. 2013;29 (2):132-137. doi:10.1097/AJP.0b013e3182490a17

81. Cohen SP, Abdi S. Lateral branch blocks as a treatment for sacroiliac joint pain: a pilot study. Reg Anesth Pain Med. 2003;28(2):113-119.

82. Cohen SP, Strassels SA, Kurihara C, et al. Outcome predictors for sacroiliac joint (lateral branch) radiofrequency denervation. Reg Anesth Pain Med. 2009;34(3):206-214. doi:10.1097/ AAP.0b013e3181958f4b

83. Ho KY, Hadi MA, Pasutharnchat K, Tan KH. Cooled radiofrequency denervation for treatment of sacroiliac joint pain: two-year results from 20 cases. J Pain Res. 2013;6:505. doi:10.2147/JPR.S46827

84. Kapural L, Nageeb F, Kapural M, Cata JP, Narouze S, Mekhail N. Cooled radiofrequency system for the treatment of chronic pain from sacroiliitis: the first case-series. Pain Pract. 2008;8 (5):348-354. doi:10.1111/j.1533-2500.2008.00231.x

85. Karaman H, Kavak GÖ, Tüfek A, et al. Cooled radiofrequency application for treatment of sacroiliac joint pain. Acta neurochirurgica. 2011;153(7):1461-1468. doi:10.1007/s00701-011-1003-8

86. Schmidt PC, Pino CA, Vorenkamp KE. Sacroiliac joint radiofrequency ablation with a multilesion probe: a case series of 60 patients. Anesth Analg. 2014;119(2):460-462. doi:10.1213/ ANE.0000000000000282

87. Speldewinde GC. Outcomes of percutaneous zygapophysial and sacroiliac joint neurotomy in a community setting. Pain Med. 2011;12(2):209-218. doi:10.1111/j.1526-4637.2010.01022.x

88. Stelzer W, Aiglesberger M, Stelzer D, Stelzer V. Use of cooled radiofrequency lateral branch neurotomy for the treatment of sacroiliac joint-mediated low back pain: a large case series. Pain Med. 2013;14(1):29-35. doi:10.1111/pme.12014

89. Yin W, Willard F, Carreiro J, Dreyfuss P. Sensory stimulation-guided sacroiliac joint radiofrequency neurotomy: technique based on neuroanatomy of the dorsal sacral plexus. Spine. 2003;28 (20):2419-2425. doi:10.1097/01.BRS.0000085360.03758.C3

90. Roberts SL, Burnham RS, Ravichandiran K, Agur AM, Loh EY. Cadaveric study of sacroiliac joint innervation: implications for diagnostic blocks and radiofrequency ablation. Reg Anesth Pain Med. 2014;39(6):456-464. doi:10.1097/AAP.0000000000000156

91. Weinstein S, Yelin E, Watkins-Castillo, S. United States bone and joint initiative: the Burden of Musculoskeletal Diseases in the United States (BMUS), fourth edition; 2020. Rosemont, IL. Available from: http://www.boneandjointburden.org. Accessed August 24, 2021.

92. Cisternas MG, Murphy L, Sacks JJ, Solomon DH, Pasta DJ, Helmick CG. Alternative methods for defining osteoarthritis and the impact on estimating prevalence in a us population-based survey. Arthritis Care Res (Hoboken). 2016;68(5):574-580. doi:10.1002/acr.22721
93. Bhatia A, Peng P, Cohen SP. Radiofrequency procedures to relieve chronic knee pain: an evidence-based narrative review. Reg Anesth Pain Med. 2016;41(4):501-510. doi:10.1097/ AAP.0000000000000414

94. Choi WJ, Hwang SJ, Song JG, et al. Radiofrequency treatment relieves chronic knee osteoarthritis pain: a double-blind randomized controlled trial. Pain. 2011;152(3):481-487.

95. Ikeuchi M, Ushida T, Izumi M, Tani T. Percutaneous radiofrequency treatment for refractory anteromedial pain of osteoarthritic knees. Pain Med. 2011;12:546-551. doi:10.1111/j.15264637.2011.01086.x

96. Protzman NM, Gyi J, Malhotra AD, Kooch JE. Examining the feasibility of radiofrequency treatment for chronic knee pain after total knee arthroplasty. $P M \& R$. 2014;6:373-376. doi:10.1016/j. pmrj.2013.10.003

97. Bellini M, Barbieri M. Cooled radiofrequency system relieves chronic knee osteoarthritis pain: the first case-series. Anaesthesiol Intensive Ther. 2015;47:30-33. doi:10.5603/AIT.2015.0003

98. Clendenen S, Greengrass R, Whalen J, O'Connor MI. Infrapatellar saphenous neuralgia after TKA can be improved with ultrasound-guided local treatments. Clin Orthop Relat Res. 2015;473:119-125. doi:10.1007/s11999-014-3812-6

99. Jamison DE, Cohen SP. Radiofrequency techniques to treat chronic knee pain: a comprehensive review of anatomy, effectiveness, treatment parameters, and patient selection. J Pain Res. 2018;11:1879-1888. doi:10.2147/JPR.S144633

100. Sarı S, Aydın ON, Turan Y, Özlülerden P, Efe U, Kurt Ömürlü İ. Which one is more effective for the clinical treatment of chronic pain in knee osteoarthritis: radiofrequency neurotomy of the genicular nerves or intra-articular injection? Int J Rheum Dis. 2018;21(10):1772-1778. doi:10.1111/1756-185X.12925

101. Shen WS, Xu XQ, Zhai NN, Zhou ZS, Shao J, Yu YH. Radiofrequency thermocoagulation in relieving refractory pain of knee osteoarthritis. Am J Ther. 2017;24(6):e693-e700. doi:10.1097/MJT.0000000000000393

102. Qudsi-Sinclair S, Borrás-Rubio E, Abellan-Guillén JF, Padilla Del Rey ML, Ruiz-Merino G. A comparison of genicular nerve treatment using either radiofrequency or analgesic block with corticosteroid for pain after a total knee arthroplasty: a double-blind, randomized clinical study. Pain Pract. 2017;17(5):578-588. doi:10.1111/papr.12481

103. El-Hakeim EH, Elawamy A, Kamel EZ, et al. Fluoroscopic guided radiofrequency of genicular nerves for pain alleviation in chronic knee osteoarthritis: a single-blind randomized controlled trial. Pain Physician. 2018;21(2):169-177.

104. McCormick ZL, Reddy R, Korn M, et al. A prospective randomized trial of prognostic genicular nerve blocks to determine the predictive value for the outcome of cooled radiofrequency ablation for chronic knee pain due to osteoarthritis. Pain Med. 2018;19(8):1628-1638. doi:10.1093/pm/pnx286

105. Gulec E, Ozbek H, Pektas S, Isik G. Bipolar versus unipolar intraarticular pulsed radiofrequency thermocoagulation in chronic knee pain treatment: a prospective randomized trial. Pain Physician. 2017;20(3):197-206. doi:10.36076/ppj.2017.206

106. Hong T, Wang H, Li G, Yao P, Ding Y. Systematic review and meta-analysis of 12 randomized controlled trials evaluating the efficacy of invasive radiofrequency treatment for knee pain and function. Biomed Res Int. 2019;2019:9037510. doi:10.1155/2019/9037510

107. Yuan Y, Wen S, Qian H, et al. Clinical observation of pulsed radiofrequency in treatment of knee osteoarthritis. Int J Clin Exp Med. 2016;9:20050-20055.

108. Rahimzadeh P, Imani F, Faiz SH, Entezary SR, Nasiri AA, Ziaeefard M. Investigation the efficacy of intra-articular prolotherapy with erythropoietin and dextrose and intra-articular pulsed radiofrequency on pain level reduction and range of motion improvement in primary osteoarthritis of knee. $J$ Res Med Sci. 2014;19(8):696-702. 
109. Shen GC, Huang ZY, Li Z, Zhang YB, Wei FQ. Clinical observation of high temperature radiofrequency combined with intra-articular injection of ozonatewater for the treatment of chronic knee osteoarthritis. Zhejiang J Trauma Surg. 2017;22 (5):938-940.

110. Yang GQ, Zhang J, Liao W, Zhou Q, Xie Z, Wu XH. Clinical effects of genicular nerve radiofrequency ablation for the treatment of intractable knee osteoarthritic pain. Prog Mod Biomed. 2015;15(32):6272-6274.

111. Yi YS, Wang SJ, Liu CS, Yu JM, Kou DW. Effects of genicular nerve radiofrequency ablation combined with intra-articular injection of sodium hyaluronate on the treatment of refractory knee osteoarthritic pain. Chin J Pain Med. 2012;18(6):322-324.

112. Hu Y, Tang JS, Hou SX, et al. Clinical observation of pulsed radiofrequency in patients with knee osteoarthritis. Chin J Pain Med. 2016;22(7):514-518.

113. Yang XL, Pang YL, Huang H, Zheng J, Yang Q, Mei DC. Clinical observation of pain point nerve block combined with radiofrequency ablation of genicular nerves in the treatment of knee osteoarthritis. Chin Manipul Rehabil Med. 2013;4(8):96-98.

114. Orduña Valls JM, Vallejo R, López Pais P, et al. Anatomic and ultrasonographic evaluation of the knee sensory innervation: a cadaveric study to determine anatomic targets in the treatment of chronic knee pain. Reg Anesth Pain Med. 2017;42:90-98. doi:10.1097/AAP.0000000000000516

115. Tran J, Peng PWH, Lam K, Baig E, Agur AMR, Gofeld M. Anatomical study of the innervation of anterior knee joint capsule: implication for image-guided intervention. Reg Anesth Pain Med. 2018;43(4):407-414. doi:10.1097/AAP.0000000000000778

116. Tran J, Peng P, Agur A. Evaluation of nerve capture using classical landmarks for genicular nerve radiofrequency ablation: 3D cadaveric study. Reg Anesth Pain Med. 2020;45(11):898-906. doi:10.1136/rapm-2020-101894

117. Fonkoue L, Behets CW, Steyaert A, et al. Current versus revised anatomical targets for genicular nerve blockade and radiofrequency ablation: evidence from a cadaveric model. Reg Anesth Pain Med. 2020;45(8):603-609. doi:10.1136/rapm-2020-101370

118. Fonkoue L, Behets CW, Steyaert A, et al. Accuracy of fluoroscopic-guided genicular nerve blockade: a need for revisiting anatomical landmarks. Reg Anesth Pain Med. 2019; 44 (10):950-958.

119. Fonkoué L, Behets C, Kouassi JK, et al. Distribution of sensory nerves supplying the knee joint capsule and implications for genicular blockade and radiofrequency ablation: an anatomical study. Surg Radiol Anat. 2019;41(12):1461-1471. doi:10.1007/ s00276-019-02291-y

120. Huang Y, Deng Q, Yang L, et al. Efficacy and safety of ultrasound-guided radiofrequency treatment for chronic pain in patients with knee osteoarthritis: a systematic review and meta-analysis. Pain Res Manag. 2020;2020:2537075. doi:10.1155/2020/2537075

121. Sari S, Aydin ON, Turan Y, et al. Which imaging method should be used for genicular nerve radio frequency thermocoagulation in chronic knee osteoarthritis? J Clin Monit Comput. 2017;31:797-803. doi:10.1007/s10877-016-9886-9

122. House LM, Korn MA, Garg A, et al. Severity of knee osteoarthritis and pain relief after cooled radiofrequency ablation of the genicular nerves. Pain Med. 2019;20(12):2601-2603. doi: $10.1093 / \mathrm{pm} / \mathrm{pnz} 095$

123. Santana Pineda MM, Vanlinthout LE, Moreno Martín A, van Zundert J, Rodriguez Huertas F, Novalbos Ruiz JP. Analgesic effect and functional improvement caused by radiofrequency treatment of genicular nerves in patients with advanced osteoarthritis of the knee until 1 year following treatment. Reg Anesth Pain Med. 2017;42(1):62-68. doi:10.1097/AAP.0000000000 000510
124. Gohritz A, Kaiser E, Guggenheim M, Dellon A, Rüdinger N. (1832-1896), his description of joint innervation in 1857, and the history of surgical joint denervation. J Reconstr Microsurg. 2018;34:21-28. doi:10.1055/s-0037-1606272

125. Gardner E. The innervation of the hip joint. Anat Rec. 1948;101:353-371. doi:10.1002/ar.1091010309

126. Short AJ, Barnett JJG, Gofeld M, et al. Anatomic study of innervation of the anterior hip capsule: implication for image-guided intervention. Reg Anesth Pain Med. 2017; 43 (2):186-192.

127. Akkaya T, Comert A, Kendir S, et al. Detailed anatomy of accessory obturator nerve blockade. Minerva Anestesiol. 2008;74:119-122.

128. Sim IW, Webb T. Anatomy and anaesthesia of the lumbar somatic plexus. Anaesth Intensive Care. 2004;32:178-187. doi:10.1177/ 0310057X0403200204

129. Okada K. New approach to the pain of the hip joint. Pain Res. 1993;8:125-135. doi:10.11154/pain.8.125

130. Kawaguchi M. Percutaneous radiofrequency lesioning of sensory branches of the obturator and femoral nerves for the treatment of hip joint pain. Reg Anesth Pain Med. 2001;26:576-581. doi:10.1053/rapm.2001.26679

131. Rivera F, Mariconda C, Annaratone G. Percutaneous radiofrequency denervation in patients with contraindications for total hip arthroplasty. Orthopedics. 2012;35: e302-e305. doi:10.3928/ 01477447-20120222-19

132. Kapural L, Jolly S, Mantoan J, Badhey H, Ptacek T. Cooled radiofrequency neurotomy of the articular sensory branches of the obturator and femoral nerves - combined approach using fluoroscopy and ultrasound guidance: technical report, and observational study on safety and efficacy. Pain Physician. 2018;1:279-284. doi:10.36076/ppj.2018.3.279

133. Naber J, Lee N, Kapural L. Clinical efficacy assessment of cooled radiofrequency ablation of the hip in patients with avascular necrosis. Pain Manag. 2019;9:355-359. doi:10.2217/pmt-2018-0083

134. Chaiban G, Paradis T, Atallah J. Use of ultrasound and fluoroscopy guidance in percutaneous radiofrequency lesioning of the sensory branches of the femoral and obturator nerves. Pain Pract. 2014;14:343-345. doi:10.1111/papr.12069

135. Stone J, Matchett G. Combined ultrasound and fluoroscopic guidance for radiofrequency ablation of the obturator nerve for intractable cancer-associated hip pain. Pain Physician. 2014;17:E83-E87.

136. Gupta G, Radhakrishna M, Etheridge P, Besemann M, Finlayson RJ. Radiofrequency denervation of the hip joint for pain management: case report and literature review. US Army Med Dep J. 2014;2014:41-51.

137. Bhatia A, Hoydonckx Y, Peng P, Cohen SP. Radiofrequency procedures to relieve chronic hip pain: an evidence-based narrative review. Reg Anesth Pain Med. 2018;43:72-83. doi:10.1097/ AAP.0000000000000694

138. Headache Classification Committee of the International Headache Society (HIS). The International classification of headache disorders, 3rd Ed. Cephalalgia. 2013;33:629-808. doi:10.1177/ 0333102413485658

139. Vanelderen $P$, Rouwette T, De Vooght $P$, et al. Pulsed radiofrequency for the treatment of occipital neuralgia: a prospective study with 6 months of follow-up. Reg Anesth Pain Med. 2010;35(2):148-151. doi:10.1097/AAP.0b013e3181d24713

140. Huang JH, Galvagno SM, Hameed M, et al. Occipital nerve pulsed radiofrequency treatment: a multi-center study evaluating predictors of outcome. Pain Med. 2012;13(4):489-497. doi:10.1111/j.1526-4637.2012.01348.x

141. Choi HJ, Oh IH, Choi SK, Lim YJ. Clinical outcomes of pulsed radiofrequency neuromodulation for the treatment of occipital neuralgia. $J$ Korean Neurosurg Soc. 2012;51(5):281-285. doi:10.3340/jkns.2012.51.5.281 
142. Vanderhoek MD, Hoang HT, Goff B. Ultrasound-guided greater occipital nerve blocks and pulsed radiofrequency ablation for diagnosis and treatment of occipital neuralgia. Anesth Pain Med. 2013;3(2):256-259. doi:10.5812/aapm.10985

143. $\mathrm{Vu} \mathrm{T}$, Chhatre A. Cooled radiofrequency ablation for bilateral greater occipital neuralgia. Case Rep Neurol Med. 2014;2014:257373.

144. Cohen SP, Peterlin BL, Fulton L, et al. Randomized, double-blind, comparative-effectiveness study comparing pulsed radiofrequency to steroid injections for occipital neuralgia or migraine with occipital nerve tenderness. Pain. 2015;156 (12):2585-2594.
145. Finiels PJ, Batifol D. The treatment of occipital neuralgia: review of 111 cases. Neurochirurgie. 2016;62(5):233-240. doi:10.1016/j. neuchi.2016.04.004

146. Hoffman LM, Abd-Elsayed A, Burroughs TJ, Sachdeva H. Treatment of occipital neuralgia by thermal radiofrequency ablation. Ochsner J. 2018;18(3):209-214. doi:10.31486/ toj.17.0104
Journal of Pain Research

\section{Publish your work in this journal}

The Journal of Pain Research is an international, peer reviewed, open access, online journal that welcomes laboratory and clinical findings in the fields of pain research and the prevention and management of pain. Original research, reviews, symposium reports, hypothesis formation and commentaries are all considered for publication. The manuscript

Submit your manuscript here: https://www.dovepress.com/journal-of-pain-research-journal
Dovepress

management system is completely online and includes a very quick and fair peer-review system, which is all easy to use. Visit http:// www.dovepress.com/testimonials.php to read real quotes from published authors. 